\title{
A "Lei da Disparidade Curvilinear": Análise Exploratória com Dirigentes e Eleitores do PMDB de Belo Horizonte
}

\author{
The "Law of Curvilinear Disparity": Exploratory Analysis with \\ Leaders and Electors of PMDB in Belo Horizonte
}

\section{Helcimara de Souza Telles Paulo Victor Melo}

\section{Resumo}

Este artigo propõe-se a analisar o vínculo entre eleitores e partidos, utilizando como referência teórica a "Lei de Disparidade Curvilinear". De acordo com esta lei, em função da necessidade de êxito eleitoral, os líderes dos partidos tendem a ser menos radicais em suas posiçôes do que os seus militantes, assemelhando-se, assim, aos seus eleitores. Para testar a hipótese de vínculos ideológicos entre dirigentes partidários e eleitores, foram realizadas entrevistas com os membros da Executiva Municipal do PMDB de Belo Horizonte e um survey com eleitores desta cidade, em 2008.

\section{Palavras-chave}

Partidos Políticos; Ideologia; Lei da Disparidade Curvilinear; PMDB.

\section{Abstract}

This paper seeks to examine the link between voters and parties, using as theoretical reference the "Law of Curvilinear Disparity". According to this law, depending on the need for electoral success, the party leaders tend to be less radical in their positions than their militants, resembling to their voters. To test the hypothesis of ideological linkages between the party leaders and voters, interviews were conducted in 2008 with the Members of the Municipal Executive Commission of the PMDB in Belo Horizonte as well as a survey with voters of this city.

\section{Keywords}

Political Parties; Ideology; Law of Disparity Curvilinear; PMDB. 


\section{Introdução ${ }^{1}$}

Os partidos políticos são instituições relevantes do sistema democrático representativo, pois são os responsáveis pela organização das disputas eleitorais, estruturação dos governos e vocalização dos anseios dos cidadãos (SARTORI, 1976). Contudo, o partido não pode ser tratado como um simples reflexo da mobilização social, da ideologia ou das oligarquias. Kitschelt (1989) argumenta que as teorias dos sistemas partidários geralmente tratam a organização partidária como uma "caixa preta”, no qual os atores se adaptam racionalmente aos constrangimentos e oportunidades oferecidos pelo mercado eleitoral. Assim como os economistas explicam o comportamento do consumidor no mercado, as teorias sistêmicas de partidos postulam uma lógica funcional ou evolutiva que regeria o comportamento dos militantes do partido, orientando-os para o sucesso na competição eleitoral.

De acordo com Kitschelt (1989), nas abordagens sobre os partidos políticos, poucos esforços têm sido feitos pela literatura internacional para vincular os sistemas e os níveis de análise organizacional. Como consequência, o partido é tratado como algo estático, o que contribui pouco para explicar a variação intertemporal da organização partidária. No Brasil, embora possam ser encontrados inúmeros estudos sobre identificação partidária (CASTRO, 1994; NICOLAU, 1996; CARREIRÃO e KINZO, 2004; KINZO, 2005; CARREIRÁO, 2007; VEIGA, 2011; PAIVA e TAROUCO, 2011; BRAGA e PIMENTEL JR, 2011; TELLES e STORNI, 2011), há escassas análises sobre os vínculos estabelecidos entre os partidos e seus eleitores, como proposto por Kitschelt (2000). A maior parte dos estudos sobre os partidos políticos analisou o desempenho eleitoral e a estrutura do Partido dos Trabalhadores (MENEGUELO, 1989; KECK, 1991; MELO, 1994; TELLES, 1997 e 2003; RIBEIRO, 2008; VILLA, 2009). Mais recentemente, começam a surgir alguns estudos sobre o Partido do Movimento Democrático Brasileiro (PMDB) (MENEGUELLO e BIZARRO NETO, 2012; MELO, 2013; FERREIRA e RIBEIRO, 2009), bem como sobre o Partido da Social Democracia Brasileira (PSDB) (ROMA, 1999; DULCI, 2010). Com raras exceções, como a de Amaral (2010), que avaliou a "Lei da Disparidade Curvilinear" no PT, poucas pesquisas verificam as ideologias dos militantes, eleitores e líderes dos partidos, muito embora

\footnotetext{
${ }^{1}$ Os autores agradecem ao Instituto de Pesquisas Econômicas, Sociais e Políticas (IPESPE), com o qual o Grupo Opinião Pública possui uma parceria institucional, pelo auxílio na pesquisa de survey com os eleitores de Belo Horizonte, em 2008, cujos resultados foram utilizados para a elaboração deste artigo. Agradecemos a participação dos estudantes do Grupo de Pesquisa "Opinião Pública, Marketing Político e Comportamento Eleitoral”, pela participação nesta pesquisa e a Pedro Mundim, que participou de diversas fases desta pesquisa. Erros e inconsistências são de responsabilidade dos autores.
} 
"party members can influence political life. Therefore, the attitudes and values of 'unseen' party members may have important effects on a country's political system" (KENNEDY et al., 2006, p. 786).

Este artigo irá explorar o vínculo entre os eleitores e as lideranças municipais que ocupavam cargos no Diretório Municipal do PMDB em Belo Horizonte, em 2008. Os vínculos são indicados quando os membros dos partidos possuem semelhantes opinióes e ideologias aproximadas. O PMDB é uma das principais legendas brasileiras. Ele detém o maior número de cargos executivos e parlamentares - prefeituras, governadores de Estados, vereadores e bancada no Congresso Nacional. Além disso, possui o maior número de filiados. Em função da sua poderosa máquina eleitoral e de sua organização em diretórios em milhares de municípios brasileiros, o PMDB é convidado a compor governos de diversos matizes políticas, independente do seu posicionamento durante as disputas eleitorais.

O foco de análise serão os líderes e os eleitores identificados com o PMDB e as opiniōes e ideologias destes segmentos. Pretende-se verificar se aspectos parciais da "Lei de Disparidade Curvilinear" (MAY, 1973), se aplica a este partido. De acordo com esta lei, em função da necessidade de êxito eleitoral, os líderes dos partidos tendem a ser menos radicais em suas posições do que os seus militantes, assemelhando-se, assim aos seus eleitores. Os dirigentes partidários são mais pragmáticos: eles possuem ideologia alinhada com os eleitores, pois têm que disputar votos. Para explorar esta lei, as opinióes dos dirigentes municipais foram comparadas com a dos eleitores identificados com o PMDB 2 .

Para pesquisar os vínculos ideológicos entre lideranças peemedebistas e seus eleitores, foram realizados análises do programa partidário, entrevistas ao universo de dirigentes da Executiva Municipal e survey com eleitores, em Belo Horizonte, em 2008. Na primeira fase da pesquisa, foram examinados o Programa do partido e o seu Estatuto, que foram ratificados pela Convenção Nacional de 24 de março de 1996. Tal pesquisa serviu de referência para a produção de questionários, aplicados à Executiva Municipal do PMDB. Os resultados foram comparados com as opinióes dos eleitores, através da Pesquisa $\mathrm{BH}$ Barômetro ${ }^{3}$, filtrados pelos eleitores que se identificavam com o partido.

\footnotetext{
${ }^{2}$ Ressalvamos que um teste completo desta lei necessitaria de dados sobre os militantes partidários, não contemplados nesta pesquisa, que tem um caráter apenas exploratório. As bases de dados com a Executiva Municipais e os eleitores se referem ao ano de 2008.

${ }^{3}$ Pesquisa realizada pela Universidade Federal de Minas Gerais (UFMG), em parceria com o Instituto de Pesquisas Sociais Políticas e Econômicas (IPESPE). Foram realizadas 800 entrevistas vis-à-vis na
} 
$\mathrm{O}$ artigo foi dividido em quatro partes. A primeira apresenta a "Lei da Disparidade Curvilinear", desde a sua origem com John May (1973), bem como suas limitações teóricas e empíricas. $\mathrm{Na}$ segunda seção, serão apresentados sumariamente os principais pontos do Programa do PMDB, utilizados para a construção do instrumento de pesquisa aplicado aos dirigentes da Executiva Municipal. A terceira seção traz a caracterização dos eleitores e das lideranças investigadas nas entrevistas e nos surveys. Finalmente, na seção quatro serão explorados aspectos exploratórios da "Lei da Disparidade Curvilinear".

\section{A "Lei da Disparidade Curvilinear"}

A "Lei da Disparidade Curvilinear" (MAY, 1973) remete à diferença entre o posicionamento ideológico dos indivíduos vinculados a um partido político, no qual alguns membros são considerados mais radicais e outros mais pragmáticos e moderados. Os partidários são divididos em grupos, de acordo com a sua posição de poder na estrutura interna e no suporte dado ao partido: os líderes, com alto status; os sublíderes e os votantes regulares do partido. Líderes são as lideranças do partido e os indivíduos que disputam cargos eletivos; sublíderes são os militantes do partido e, finalmente, os não-líderes são os eleitores que votam regularmente e aqueles identificados com o partido. A posição de poder dos indivíduos nos partidos é hierárquica, como pode ser observado pelo Quadro 1.

O termo curvilinear se refere a uma geometria da distribuição das preferências ideológicas. Através da média dos posicionamentos ideológicos dos partidários em um contínuo, pode-se observar uma aproximação de seus extremos (lideranças e eleitores); ao passo que os membros sem posições de liderança (não-líderes) estariam em um ponto fora da reta, configurando assim uma curva de opinióes.

cidade de Belo Horizonte, em setembro de 2008. Margem de erro 3,1 pontos percentuais. Intervalo de Confiança: 95\%. Pesquisa por cota e domiciliar. 
Quadro 1 - Estratos Partidários: Tipologia de May (1973)

\begin{tabular}{|c|c|}
\hline Líderes & $\begin{array}{r}\text { Executivos do governo (Presidente; Primeiro Ministro; Governador, membros do } \\
\text { gabinete); legisladores (deputados), cúpula nacional / federal dos partidos; maiores } \\
\text { contribuintes dos partidos; candidatos por um cargo no governo; delegados das } \\
\text { convençôes nacionais dos partidos. }\end{array}$ \\
\hline Sublíderes & $\begin{array}{r}\text { Cúpula regional dos partidos; delegados das convençôes regionais dos partidos, } \\
\text { funcionários regionais dos partidos inclusive os eleitores dos candidatos partidários; } \\
\text { integrantes dos partidos sem cargo partidário. }\end{array}$ \\
\hline Não-líderes & Eleitores dos partidos; eleitores ocasionais dos partidos. \\
\hline
\end{tabular}

Fonte: Elaborado a partir de May (1973).

A “Lei de Disparidade Curvilinear" se baseia na teoria da rational choice, sobretudo no princípio segundo o qual os atores racionais antecipam os resultados das ações, antes de fazerem escolhas. Embora May (1973) não tenha sido explícito, ele supõe que os atores tenham preferências completas e transitivas e agem com segurança. Em termos gerais, isso significa que os líderes partidários conhecem as opiniōes dos não-líderes e dos eleitores. Os elementos implícitos e explícitos na "Lei da Disparidade Curvilinear" podem ser enumerados em níveis de estratificação, pressupostos e preferências dos atores, conforme mostrado no Quadro 2: 
Quadro 2 - Lei da Disparidade Curvilinear: Partido, Níveis de Liderança e Atores

\begin{tabular}{|c|c|c|}
\hline $\begin{array}{l}\text { Níveis de } \\
\text { hierarquia }\end{array}$ & Pressupostos & $\begin{array}{l}\text { Preferências dos } \\
\text { Atores }\end{array}$ \\
\hline \multirow{7}{*}{$\begin{array}{l}\text { Estratificação nos } \\
\text { partidos em três } \\
\text { níveis de hierarquia: } \\
\text { 1. Líderes; } \\
\text { 2. Sublíderes; } \\
\text { 3. Não-líderes. }\end{array}$} & $\begin{array}{l}\text { a) As opiniões dos membros de um nível são } \\
\text { representadas pela opinião média dos membros, o } \\
\text { que resulta na consideração de um nível como um } \\
\text { ator homogêneo representado pela opinião média. }\end{array}$ & $\begin{array}{l}\text { i) Atores têm } \\
\text { preferências completas e } \\
\text { transitivas }\end{array}$ \\
\hline & $\begin{array}{l}\text { b) Apenas no nível dos líderes existem boas } \\
\text { recompensas pelo trabalho, relacionadas com os } \\
\text { cargos, de onde advêm dinheiro, poder e prestígio. }\end{array}$ & $\begin{array}{c}\text { ii) Atores têm } \\
\text { informaçóes completas. }\end{array}$ \\
\hline & $\begin{array}{l}\text { c) O nível dos líderes é relacionado com muito } \\
\text { trabalho; o nível dos sublíderes é relacionado com } \\
\text { muito trabalho; o nível dos não-líderes é } \\
\text { relacionado com apenas um pouco de trabalho. }\end{array}$ & $\begin{array}{c}\text { iii) Na esfera política a } \\
\text { primeira preferência dos } \\
\text { líderes é a } \\
\text { permanência ou a } \\
\text { extensão do poder } \\
\text { deles; a segunda } \\
\text { preferência é a luta } \\
\text { pelos objetivos } \\
\text { ideológicos deles }\end{array}$ \\
\hline & $\begin{array}{l}\text { d) Líderes detêm o poder de decidir políticas sociais } \\
\text { em função dos cargos que ocupam, mas eles } \\
\text { precisam da ajuda dos não-líderes, dos sublíderes e } \\
\text { dos votos dos eleitores para manterem ou } \\
\text { estenderem o poder político deles. }\end{array}$ & $\begin{array}{l}\text { i) Na esfera política, a } \\
\text { única preferência. } \\
\text { importante dos } \\
\text { sublíderes e não-líderes } \\
\text { é a luta pelos objetivos } \\
\text { ideológicos deles. }\end{array}$ \\
\hline & $\begin{array}{l}\text { e) Sublíderes têm a possibilidade de influenciar as } \\
\text { açóes e decisóes dos líderes na área política em } \\
\text { função da importância deles, pois gerem dinheiro } \\
\text { pelos partidos, executam a gestão dos partidos, } \\
\text { escolhem os candidatos dos partidos e ajudam os } \\
\text { líderes a obter informações sobre as preferências dos } \\
\text { eleitores. Mas, eles não são eleitos pelos não-líderes } \\
\text { ou convocados pelos líderes }\end{array}$ & $\begin{array}{l}\text { v) Atores podem ser } \\
\text { radicais (esquerda/ } \\
\text { direita) ou moderados }\end{array}$ \\
\hline & $\begin{array}{l}\text { f) Não-líderes detêm o poder de influenciar líderes } \\
\text { em função dos votos deles, dos quais os líderes } \\
\text { precisam para permanecer ou estender o poder } \\
\text { político, mas eles não são eleitos nem convocados }\end{array}$ & $\begin{array}{l}\text { vi) Quanto mais } \\
\text { trabalho um ator quer } \\
\text { se encarregar na área } \\
\text { política mais radicais } \\
\text { são as opiniōes dele }\end{array}$ \\
\hline & $\begin{array}{l}\text { g) A influência per capita dos sublíderes sobre os } \\
\text { líderes é maior do que a influência per capita dos } \\
\text { não-líderes }\end{array}$ & \\
\hline
\end{tabular}

Fonte: GRUPO OPINIÃO PÚBLICA e IPESPE (2008), elaborado a partir de May (1973). 
Dos pressupostos de May (1973), resulta que para se tornar um líder, o indivíduo precisa se dedicar à política, mas não tem certeza sobre a recompensa deste trabalho, que seria o acesso a cargos. Os radicais são mais dedicados ao trabalho partidário e, consequentemente, mais ativos na área política (pressuposto vi). Então, os líderes são mais radicais do que os não-líderes, mas menos radicais do que os sublíderes. Embora sublíderes tenham quase tanto trabalho como os líderes na área política (pressuposto c), ambos têm opinióes igualmente radicais (pressuposto vi), ao contrário dos sublíderes, os quais não dependem de ninguém (pressuposto e).

Os líderes são, em geral, dependentes dos votos dos não-líderes e dos eleitores (pressuposto d; iii), os quais são mais moderados do que os líderes e sublíderes (pressuposto vi). Pelo fato dos líderes também serem dependentes da ajuda dos sublíderes (pressuposto d; e; iii), eles perseguem políticas que são localizadas entre as opinióes (mais moderadas) dos não-líderes e as opinióes (mais radicais) dos sublíderes.

Caso os pressupostos de May (1973) sejam válidos, seu modelo teria a capacidade de prever as opiniōes políticas gerais dos atores partidários. A dificuldade dos líderes e não-líderes para controlar os sublíderes faz com que os líderes se afastem das opinióes moderadas dos não-líderes e dos eleitores, o que os leva a adotar políticas mais radicais. Neste sentido, os sublíderes são mais radicais que os não líderes. Caso não houvesse influência dos sublíderes sobre os líderes, as políticas decididas pelos líderes seriam mais moderadas e mais próxima das opiniões dos não-líderes.

O modelo de May (1973) presume que os eleitores dos partidos são pragmáticos, correspondendo ao eleitor médio dowsiano (DOWNS, 1999); ao contrário dos militantes, que seriam os portadores de atitudes políticas mais radicais. $\mathrm{E}$, os líderes anseiam pelos votos para conquistarem ou manterem cargos. Por esta razão, as lideranças são levadas a uma posição mais próxima à dos eleitores. Já os militantes, uma vez que tem menor preocupação em assumir cargos representativos, poderiam assumir posiçóes destoantes daquelas encontradas entre os eleitores do partido.

A primeira critica apresentada a esta lei é sobre a presunção de uma homogeneidade de opinióes no interior dos subgrupos partidários. Dentro de cada camada partidária, existem membros com posições mais ou menos extremistas. A suposição de que todos possuem pensamento único seria equivocada, pois dentro do grupo denominado como membros, estão os que anseiam por disputar alguma eleição ou por ocupar cargos de liderança (KITSCHELT, 1989). Por isso, Kitschelt propóe que o grupo de militantes seja dividido em dois subgrupos, o grupo daqueles que anseiam por cargos - ou seja, mais pragmáticos -, e outro composto pelos militantes 
considerados ideológicos, possibilitando um maior grau de coesão entre os membros de cada subgrupo. Esta teoria alternativa é parcialmente testada com levantamento de dados (surveys) de militantes dos partidos ecológicos belgas, Agalev e Ecolo.

Kitschelt (1989) leva em conta as contribuições de autores clássicos, que afirmam existir uma disparidade curvilínea de incentivos políticos e preferências entre os eleitores, militantes e líderes do partido. Eleitores em geral são moderados, tendendo a apoiar somente reformas sociais marginais. Os líderes do partido, interessado em captar votos e cargos políticos, irão atender a esses pontos de vista.

Como observado, um dos segmentos mais importantes para demonstrar a curva na "Lei da Disparidade Curvilinear" são os sublíderes - militantes -, que seriam os mais radicais ideologicamente. A respeito deste segmento, Kitschelt (1989) argumenta que militantes do tipo Rank-and-Files (militantes de nível médio), insistem em programas ideológicos mais radicais. Por esta razão, os partidos procuram desenvolver estratégias eleitorais apenas quando os líderes podem controlar os militantes Rank-and-Files. Deste modo, a disparidades encontradas entre os segmentos de líderes e militantes ocorrem apenas em circunstâncias específicas.

Kitschelt (1989) insere as condiçôes para a ocorrência da disparidade curvilinear, que dependem de dois tipos de estrutura: Loose Coupling (estrutura flexível) e Tightly Coupled (estrutura forte). Três condições institucionais determinam o quão flexível ou fortemente estruturada está uma organização partidária. Estas variáveis definem a extensão da curva de disparidade: o acesso a cargos de nível médio, a autoridade nacional da convenção partidária e a posição dos executivos do partido.

A disparidade é mais provável em organizações do tipo Loose Coupling (estrutura flexível), pois o processo decisório não é vertical, mas horizontal e, por isso, a autoridade política não se limita a um pequeno grupo de representantes eleitos pelos militantes. Em uma organizaçáo do tipo Loose Coupling, os militantes participam nas atividades que estão mais interessados. Assim, os pragmáticos estão sobre representados em seçôes eleitorais locais do partido, ao passo que os mais radicais são mais visíveis no nível médio. $\mathrm{E}$, os líderes não são centralizados, pois são representantes de cada tendência política. Em organizações partidárias fortemente estruturadas (Tightly Coupled), os cargos mais altos determinam as atividades; a participação democrática é restrita, pois os ativistas de base escolhem os delegados para órgáos decisórios mais elevados. Nesta estrutura, os radicais têm menor chance de dominar em cargos de nível médio.

$\mathrm{O}$ autor conclui que quanto menos restriçóes são colocadas ao acesso aos níveis médios do partido, mais provável é que os ideológicos fiquem sobre 
representados. Ideológicos se beneficiam mais de processos de seleção das conferências partidárias, que dão maior importância ao comprometimento individual do que a escolhas representativas ou indicaçooes autoritárias. Em síntese, a disparidade não é uma lei, já que ela é definida pelo modo como se estruturam as decisóes no interior da organização. A lei é apenas um caso de uma teoria mais ampla da reconstrução da interação entre os círculos eleitorais, a política partidária e a competição intrapartidária. Neste sentido, esta lei oferece pouca ajuda para vincular o funcionamento interno dos partidos com as escolhas sobre as estratégias de ação na competiçáo.

Pippa Norris (1995) quer explicar os conflitos ideológicos dentro dos partidos políticos. Ela reaplica o estudo para o Partido Trabalhista Britânico. Para verificar a lei, a autora usou os dados do British Candidate Study (BCS) (1992), que estáo baseados em uma pesquisa feita com 1320 líderes dos partidos na Inglaterra, e também dados da pesquisa British General Election Study (BES) (NORRIS, 1995). Foram consideradas as opiniões dos políticos pelas políticas sociais, econômicas e os valores deles.

Assim como May (1973), ela considera que os partidos podem ser divididos em esferas diferentes que estão relacionadas com a posição dos integrantes nos partidos (NORRIS, 1995). No caso da "Lei da Disparidade" ser válida, os sublíderes teriam uma grande influência sobre o sistema político, resultando em políticas partidárias mais radicais do que as opinióes dos eleitores e levando a um sistema partidário mais polarizado do que a sociedade (NORRIS, 1995). De acordo com Norris, o exame da lei da disparidade deve considerar todos os segmentos da teoria: os líderes, os sublíderes e os não-líderes. Além disso, deve ser analisado o universo tanto dos partidos de esquerda como os de direita. O radicalismo - variável dependente teria que ser bem definida, pois diferentes acepçóes levam a distintos resultados. Finalmente, as hierarquias dos partidos têm que ser exatas (NORRIS, 1995).

Ela divide os membros do partido em quatro estratos: líderes (integrante do Congresso e candidatos pelo Congresso); executivos (sublíderes que tem um cargo oficial nos círculos eleitorais); membros militantes (integrantes dos partidos sem cargo, mas que participam das reunióes dos partidos); e eleitores (NORRIS, 1995). De acordo com a lei de May (1973), os executivos (officers) são os integrantes mais radicais dos partidos no modelo.

O resultado esperado era o de que líderes e eleitores apresentassem um comportamento mais pragmático e semelhante, enquanto os officers fossem portadores de opinióes mais extremas. No entanto, os resultados apontaram que os líderes possuíam um comportamento mais radical em comparação aos outros 
subgrupos (NORRIS, 1995). Assim, a "Lei da Disparidade" tem pouca capacidade preditiva sobre as diferenças entre as opiniões ideológicas dos vários integrantes de um partido.

Como Kitschelt (1989), ela assume que existem incentivos para participar em um partido e que nos diferentes estratos dos partidos - líderes ou sublíderes - existem diversos incentivos para participar. Nem todos os líderes se dedicam a um partido por causa do poder, status social ou dinheiro; nem todos os sublíderes são dedicados em função da ideologia, como supõe a lei proposta por May (NORRIS, 1995).

A lei de May (1973) também foi examinada por Méndez e Santamaria (2001), que estudaram o Partido Socialista Obrero Español (PSOE). Os autores apresentam uma análise sobre o perfil ideológico dos delegados do PSOE, a partir de entrevistas realizadas durante o seu $34^{\circ}$ Congresso, ocorrido em 1997. O estudo abordou as características e as atitudes dos distintos grupos internos do partido, pretendendo descobrir se haveria diferenças sócio-demográficas ou de atitude entre cada um desses grupos. A principal questão estudada seria a da diversidade ideológica entre os diferentes setores do partido e a relação entre a distribuição de preferências e o tipo de estratégia eleitoral que adotam.

O resultado das entrevistas realizado mostrou uma tendência dos delegados se situarem em posiçôes de centro-esquerda e de se localizarem em posiçóes mais à esquerda que aquelas que atribuem ao PSOE como um todo. Havia uma notável homogeneidade entre os delegados do PSOE presentes no $34^{\circ}$ Congresso, que não apresentaram diferenças significativas no plano ideológico em termos de idade, gênero, religiosidade, tempo de filiação, desempenho em cargo público ou orientação mais pragmática. Mas, isso não significa que tenham as mesmas opinióes. A análise desenvolvida revelou um perfil dos delegados mais inclinado à esquerda do que os eleitores. Por fim, se póe em evidência que, em grande medida, a avaliação acerca da verificação da tese de May (1973) depende da definição que de líderes de um partido e de os delegados podem ou não serem incluídos neste estrato.

De forma indireta, Telles (2009) reaplica a teoria para o Partido dos Trabalhadores (PT), em Belo Horizonte, e encontra o mesmo padrão de respostas apontadas por Norris (1995), no qual as lideranças (membros da Executiva Municipal) são mais extremistas do que os militantes (candidatos a vereador), o que contraria a Lei da Disparidade, que supóe direção oposta a esta. Telles argumenta que este resultado ocorre em função da heterogeneidade ideológica e a origem diversificada dos seus militantes, No entanto, uma estrutura Loosing Coupled-maior participação das bases e o recrutamento mais flexível -, como parecia ser o caminho do PT, poderia resultar na gradual introdução gradual de lideranças mais pragmáticas 
e moderadas e mais próximas das bases partidárias, o que reforçaria a hipótese de Kitschelt (1989), segundo a qual a lei da disparidade depende dos mecanismos como se processam as decisões na estrutura interna.

Kennedy, Lyons e Fitzgerald (2006) testaram a "Lei da Disparidade" para o caso do Irish Labour Party - Partido Trabalhista Irlandês. Eles exploraram uma parte da lei de May (1973), que é a premissa de que os membros do partido devem ter posiçóes mais extremadas do que os eleitores e a ideia de que a opinião dos vários estratos de membros partidários deveria ser significativamente diferente uns em relação aos outros. Em particular, os autores pretenderam trazer para a literatura uma análise empírica da diferenciação proposta por Kitschelt (1989), que analisou os estratos partidários como ideológicos e pragmáticos. Os autores esperavam que os membros ideológicos fossem mais extremistas do que os pragmáticos, e que fossem mais extremistas do que os eleitores.

Para definir a estrutura hierárquica do partido, os autores utilizam quatro medidas. A primeira medida é o auto-posicionamento em uma escala de ativismo. Outras duas medidas referem-se aos conceitos propostos por Kitschelt (1989) de "ideológicos" e "pragmáticos". As questôes propostas tinham a ver com os seguintes trade-offs: cargos $\mathrm{x}$ pureza das políticas; atividade parlamentar $\mathrm{x}$ trabalho eleitoral (busca por mais votos). O ultimo indicador referia-se à ocupação de cargos dentro do partido e caso a resposta fosse afirmativa, qual seria esse cargo.

Neste estudo, a variável dependente é a "opinião estruturada dos membros sobre seu partido". Para os autores, a opinião estruturada do partido estará baseada nos posicionamentos de seus membros referentes às clivagens ideológicas da sociedade. As clivagens consideradas no estudo foram: econômica, esquerda-direita, moral liberal-conservadora e nacionalismo. Segundo os pesquisadores, um dos problemas chaves enfrentados pela pesquisa foi a de identificar parâmetros para a mensuração das categorias "ideológicos" e "pragmáticos". Apenas o uso de uma escala de onze pontos não foi suficiente para fazer tal recorte, já que houve posicionamentos dos membros em quase todos os pontos da escala de maneira relativamente uniforme.

Os resultados sugerem que a lei de May (1973) deve possuir melhor aplicação no exame de pequenos partidos em sistemas multipartidários tipificados pela formação de governos de coalizão. A análise dos dados mostrou pouca evidencia de uma estruturação da opinião dos membros de acordo com seus estratos, além de pouca evidencia de que a opiniáo dos eleitores seja geralmente mais moderada do que a dos membros do partido.

A pesquisa com o Partido Trabalhista Irlandês demonstrou que a observação da lei de May (1973) depende da estratégia político-eleitoral que os próprios partidos 
põem em prática. Fica evidente também que os partidos políticos não são atores unitários. Os membros possuem diferentes motivações e ostentam diferentes preferências ideológicas. Entretanto, tais diferenças não podem simplesmente serem inferidas pela posição de um membro dentro do partido ou do seu nível de "atividade" dentro do mesmo.

Seguindo a mesma linha traçada por Telles (1997; 2009), Roma (2003; 2006) traz a discussão para o caso brasileiro, comparando dois dos principais partidos do atual período democrático: o PT e o PSDB. Analisando a trajetória e a estrutura de organizaçáo interna dos partidos, o autor aponta os motivos que levaram ao sucesso eleitoral prematuro do PSDB. O PSDB tem uma origem parlamentar e, por isso, foi mais fácil a desvinculação de bandeiras ideológicas e a adaptação ao modelo eleitoral brasileiro. Ao adotar políticas mais pragmáticas, o PSDB tornou-se capaz de ser mais bem aceito pelo eleitorado. Já o PT nasce de demandas da sociedade e distante das esferas de governo, tendo a sua origem vinculada a movimentos sociais, operários, intelectuais, exilados políticos e por setores da Igreja. E, devido à maior possibilidade de manifestação dos militantes na estrutura interna do partido, foi limitada a possibilidade de desvincular-se das bandeiras mais radicais e, por conseguinte, atrasou o seu sucesso eleitoral.

O somatório dos trabalhos de Telles (2009) e Roma (2003; 2006) sobre o caso no Brasil (ainda que os autores não tenham testado diretamente a lei da disparidade), revela a importância da discussão realizada por Kitschelt, pois confirmam a hipótese de que a trajetória e a estrutura interna dos partidos são de vital importância para a aplicação da "Lei da Disparidade Curvilinear". O PT, na sua origem, seria um exemplo de partidos Tightly Coupled enquanto o PSDB se apresenta com um partido de Loose Coupling, e a escolha por uma destas definiu a influencia dos militantes nas estratégias do partido, sendo crucial para o sucesso eleitoral da organização e, portanto, para a estruturação do sistema partidário.

O debate apresentado demonstra relevância de se estudar comparativamente a opinião dos estratos. A "Lei da Disparidade Curvilinear" é uma ferramenta útil e importante como ponto de partida para a compreensão dos partidos políticos.

\section{O programa e a ideologia do PMDB}

Antes de traçarmos os pontos que apresentam alinhamento ou desalinhamento entre a liderança municipal do PMDB, o programa partidário e os simpatizantes, faremos uma pequena descrição do programa deste partido, a partir de seus documentos. Optamos por utilizar o último Programa Nacional do PMDB, publicado em sua Convenção Nacional de 24 de Março de 1996, além do Estatuto 
do Partido, publicado pela Comissão Executiva Nacional, em 28 de março de 2007. Estes documentos estavam em vigor durante o período analisado neste trabalho.

O trabalho de pesquisa documental analisou o Programa e o Estatuto do PMDB, para testar a opinião da Executiva Municipal em relação ás diretrizes do partido. A variável dependente para a "Lei da Disparidade" é a ideologia presente nos distintos estratos partidários. Como afirma Norris (1995), a definição de ideologia tem que ser bastante clara, para realizar comparaçóes, uma vez que concepções distintas alteram os resultados e não permitem as comparações entre partidos.

No entanto, é bastante difícil encontrar nos programas dos partidos brasileiros uma concepção definida e esclarecedora que seja capaz de oferecer uma visão inequívoca sobre a ideologia proferida pelos partidos. Deste modo, este estudo explorou o Programa do PMDB (1996) e indicou alguns elementos que, quando combinados, poderiam definir a sua ideologia: a concepçáo de representação (mandato livre $\mathrm{x}$ mandato imperativo), os valores (aceitação ou rechaço à pena de morte), as relaçôes internacionais preferenciais. Além da ideologia, de acordo com Kitschelt (1989), as variáveis institucionais podem atravessar a lei da disparidade e uma das variáveis intervenientes é a estrutura do partido - se mais flexível ou mais rígida. Finalmente, foi inserida uma variável do sistema eleitoral, pois ele pode ser usado no cálculo para obtenção de votos, sobretudo por parte dos líderes: o sistema eleitoral.

O MDB (Movimento Democrático Brasileiro) tem a sua origem como partido cuja função era a de ser a voz da oposição dentro do regime autoritário e esta bandeira o unificava. A luta pela democracia foi a grande herança deixada ao PMDB, já que ele foi originado tendo como bases distintos grupos políticos: de comunistas a setores empresariais, de trabalhadores rurais e urbanos a políticos de longa tradição. $\mathrm{O}$ partido, que é apresentado pela literatura como sendo multifacetado em seu interior (KINZO, 1988), é na verdade ancorado pela busca de uma causa única: à volta a democracia.

No entanto, com o fim do bipartidarismo e a redemocratização ocorrida a partir de 1985, o PMDB perde o motivo inicial que o levou a ser criado. No país, surge uma nova agenda política, novos problemas e outros partidos relevantes, que disputam a preferência do eleitorado com PMDB. Muitos dos seus quadros passaram a buscar outras legendas, seja à direita ou à esquerda do espectro ideológico e ele passa a receber políticos com múltiplos interesses. Deste modo, afloram disputas regionais 
mais conflitivas. Estas dissonâncias levam a divisões, migrações e surgimento de novas legendas ${ }^{4}$.

\begin{abstract}
No MDB, a capacidade de articular um projeto político havia deixado de existir desde o período da transição e as condições para uma ação unitária deterioraram-se de forma evidente - desde entâo a legenda manteve-se como um agregado de interesses regionais precariamente unificados pela maximização de cargos no plano federal. O partido abandonou a pretensão de disputar a presidência, definiu como prioritária a arena estadual e passou a jogar o jogo presidencial valendo-se do aninhamento das disputas eleitorais e do caráter coalizional do presidencialismo (MELO, 2010, p. 23).
\end{abstract}

Deve-se ressaltar que os partidos competem em diálogo com a sociedade e disputam com outras forças políticas. O PMDB conquistou importantes estados nas eleições de 1982, através da bandeira de representante da oposição ao regime. Mas, a emergência do PT em 1979 e a do PSDB, em 1989, foram divisores do histórico político do PMDB. O PMDB passou a competir com estas duas novas forças, que disputarão com ele o eleitor distribuído à esquerda e ao centro do espectro ideológico. O novo cenário político impunha ao PMDB reformulaçóes em suas estratégias, uma vez que pretendia continuar crescendo eleitoralmente e, para tanto, era necessário ter um programa mais claro, já que a luta pela redemocratização havia se esgotado como bandeira política.

As mudanças acima levam o partido a reformular sua Carta Programática, que foi constituída em 1979 e cujo mote era a redemocratização. O programa original do PMDB se remete diretamente ao do MDB, resguardando os ideais de um partido que deveria lutar pela democracia e garantir o novo sistema que nascesse fosse democrático. No entanto, após as eleições de 1989, quando o PMDB sofreu uma derrota expressiva nas eleiçóes para presidente, emergiu a necessidade de se atualizar o programa partidário.

Em 1991, Orestes Quércia, Deputado Federal por São Paulo, assumiu a Presidência do partido e convocou uma comissão com o intuito de elaborar uma nova

\footnotetext{
${ }^{4} \mathrm{O}$ PSDB foi basicamente fundado por lideranças parlamentares "em busca de espaço e poder" (ROMA, 2003, p.72), dentre elas destacam-se, Franco Montoro (SP), Afonso Arinos (RJ), Pimenta da Veiga (MG), Fernando Henrique Cardoso (SP), Mário Covas (SP), José Serra (SP), Renan Calheiros (AL), Célio de Castro (MG) e Geraldo Alckmin (SP). A estrutura adotada pelo partido, basicamente parlamentar, descentralizada e sem a presença de atividades extra eleitorais fez com que o PSDB se tornasse um partido com baixa militância e dominado pelas elites dirigentes.
} 
proposta de programa partidário. Em 1992, esta comissão apresentou a primeira versão da proposta, que foi enviada para os diretórios nacionais, estaduais e municipais, para apreciação e sugestôes. Em 1993, José Fogaça, Deputado Federal pelo Rio Grande do Sul, assumiu a Presidência do partido e convoca uma segunda comissão para avaliar os comentários feitos pelos diretórios e dar prosseguimento à elaboração do novo programa partidário. No final do ano de 1993, foi apresentado o anteprojeto "Democracia: Novo Programa Partidário do PMDB". Este anteprojeto, submetido ao II Congresso Partidário, que ocorre em 24 de março de 1994, foi modificado em partes e aprovado em primeira instancia. O programa do PMDB foi enfim ratificado em 1996, dois anos após sua submissão no II Congresso Partidário (PROGRAMA DO PMDB, 1996).

Apenas um destaque quanto ao posicionamento ideológico: a literatura brasileira classifica o PMDB como um partido de centro. Em consonância com esta afirmação, Melo e Santos (2012), ao estudarem as elites legislativas da Câmara dos Deputados e das Assembleias Legislativas de 12 estados brasileiros, apontaram para uma uniformidade de opinióes entre o posicionamento ideológico dos parlamentares do PMDB e as suas atitudes políticas - conservadoras ou liberais. Os autores, com bases nos dados coletados por meio de pesquisas de opinião em situações diversas, em conjunturas diferentes e em esferas políticas distintas, encontraram valores de localização muito próximos; ou seja, encontram indícios de que apesar da não existência de uma "bandeira" unificadora, a elite partidária possui algum grau de coesão.

Quadro 3 - Posicionamento Ideológico dos Parlamentares PMDB na escala DireitaEsquerda 5 (2005 - 2012)

\begin{tabular}{|c|c|c|c|c|}
\hline & Dep. Fed. 2005 & Dep. Fed. 2010 & Dep. Est. 2007 & Dep. Est. 2012 \\
\hline Auto Localização & 4,84 & 4,79 & 5,04 & 5,24 \\
\hline Localização do Partido & 5,32 & 5,79 & 5,86 & 5,8 \\
\hline
\end{tabular}

Fonte: Elaborado pelos autores a partir de Melo e Santos (2012).

O Quadro 3 apresenta o autoposicionamento ideológico dos parlamentares do PMDB e a localização na qual os seus parlamentares alocam o partido. Os dados demonstram que a autolocalização dos parlamentares do PMDB sofreu pequena variaçáo. Os deputados federais estáo à esquerda, ao passo que os deputados estaduais estáo autolocalizados ao centro. Mas, os deputados federais do PMDB, após

\footnotetext{
${ }^{5}$ Foi perguntado aos entrevistados como eles se posicionam se um for extrema esquerda e 10 estrema direita.
} 
participarem da base de sustentação dos governos de Lula (2003/2010), classificaram o PMDB avançando em direção do centro para a direita $(5,32$ para 5,79).

Um estudo mais profundo sobre a ideologia do PMDB foi feito por Alcántara (2004), através de uma análise da situação dos partidos políticos latino-americanos, desde a perspectiva do programa partidário. $\mathrm{O}$ autor baseou-se exclusivamente nas opinióes dos membros dos partidos e nos programas partidários. A partir disso, construiu uma classificação da ideologia. Para o autor, "la dimensión del programa viene a definir lo que el partido es y no lo que el partido hace” (ALCÁNTARA, 2004, p. 2).

Os eixos programáticos indicadores de ideologia foram estabelecidos sobre binômios, em escalas combinadas. De um lado, o eixo programático - a política econômica (neoliberalismo x estatismo), atitudes e valores (direitos) e a relação dos países com o exterior (integração nacional, regionalização, globalização). De outro lado, a ideologia. A ideologia foi aferida através da escala de direita e esquerda.

O autor ressalva que o uso da escala de direita-esquerda é ainda pouco utilizada nos estudos sobre partidos latino-americanos, dado às características da região, que combina alta volatilidade e histórico de líderes caudilhistas e personalistas. No entanto, ainda com estas ressalvas, Alcántara (2004) crê que a escala ideológica pode ser um instrumento útil, mesmo porque, segundo ele, não se trata de analisar como os partidos agem, mas aferir como os partidos são e a posição ideológica de seus militantes. Ademais, o autor considera que, a despeito dos problemas da regiáo, os partidos políticos estão mais institucionalizados que em épocas anteriores, o que justifica o uso da escala.

O modelo do autor pode ser mais bem visualizado no Quadro 4. No eixo programático encontram-se as posições neoliberalismo $\mathrm{x}$ estatismo, conservadores $\mathrm{x}$ progressistas, nacionalistas $\mathrm{x}$ regionalistas. No eixo da ideologia, a autolocalização ideológica do militante e a localização do partido pelos membros dos outros partidos. Para o caso brasileiro, o autor analisou os seguintes partidos: Partido Democrático Trabalhista (PDT), Partido da Frente Liberal (PFL), Partido Progressista Brasileiro (PPB), PSDB e PT. 
Quadro 4 - Elementos para uma taxonomia dos partidos políticos latino-americanos

\begin{tabular}{|c|c|c|}
\hline \multirow{3}{*}{$\begin{array}{l}\text { Eixo de princípios } \\
\text { programáticos }\end{array}$} & Neoliberalismo - Estatismo & \multirow{3}{*}{ Escala de 1 a 10} \\
\hline & Conservador - Progressista & \\
\hline & Nacionalista - Regionalista & \\
\hline \multirow{2}{*}{ Posição ideológica } & Autolocalização partidária & \multirow{2}{*}{ Escala de 1 a 10} \\
\hline & Localização partidária & \\
\hline
\end{tabular}

Fonte: Alcántara (2004).

Em relação aos aspectos econômicos, as respostas que o Estado deve se ocupar de produzir e redistribuir renda define o "estatista". Ser favorável somente aos planos de pensão privadas, ser contra uma política industrial e de responsabilidade governamental no setor privado e a favor do livre mercado ser encarregado de determinar a produção e redistribuir rendas definem o posicionamento "neoliberal". Neste eixo, ele encontrou PMDB, PPB e PSDB como partidos intermediários - nem neoliberais nem "estatistas" -, ao passo que PT e PDT têm posição "estatista".

O segundo indicador do eixo programático diz respeito aos valores. As perguntas giraram sobre direitos civis e outros. Assim, ser favorável ao endurecimento das penas, ser a favor que as minorias devem acatar leis das culturas dominantes, ser favorável ao respeito aos valores tradicionais, ser contrário à legalidade do aborto e a definição do partido como "conservador" na posição moral e cultural, significava conservadorismo. As posições contrárias a estas foram classificadas como progressistas. Novamente, o PMDB ficou na posição "intermediária”, juntamente com o PFL, PPB e PSDB; PDT e PT são progressistas em relação aos costumes.

O último item do eixo programático é o do nacionalismo x regionalismo. Estas posições se referem à definição da política exterior que o partido possui em relação à integração regional e incorporação na economia. Os nacionalistas consideram a integração regional desvantajosa para o país e privilegiam a autonomia nacional nos assuntos econômicos, políticos e culturais. Os regionalistas têm posição contrária a estas. Mas, com exceção de dois casos de nacionalismo na América Latina, os demais partidos analisados estão na posição regionalista, que é majoritária, e a intermediária.

Finalmente, é examinado o eixo ideológico, que se refere ao autoposicionamento do membro do partido e a localização do partido por membros dos demais partidos. $\mathrm{O}$ resultado informa que os membros do PMDB se autolocalizam na posição centro-direita, mas é localizado pelos demais militantes partidários como de centro.

A partir destas categorias, o autor (ALCÁNTARA, 2004) realiza correlaçóes entre as médias das subdimensões dos princípios programáticos e a polarização 
ideológica, para estabelecer uma tipologia dos partidos políticos. O autor realizou um cruzamento dos três eixos referidos e a ideologia, chegando a três dimensóes finais: partidos reacionários, centristas e progressistas. PMDB, PPB e PSDB ficaram posicionados como "centristas"; PT e PDT, progressistas e o PFL como partido reacionário.

Este estudo confirma a ambiguidade do PMDB, pois apesar de ser classificado como partido de centro, os seus membros se autodefinem como de "centro-direita". Todavia, o estudo do autor refina o conceito de centro, pois inclui maior número de classificaçóes. No entanto, a classificação da ideologia do PMDB como de centro, confirma achados de autores brasileiros. ${ }^{6}$.

Nos programas partidários do $\mathrm{PMDB}$, com respeito à sua estrutura, tendo como base a dualidade formulada por Duverger (1980) - partidos de massas x partidos de quadros -, nota-se que, de acordo com o programa,

o PMDB é um partido de massas, que continuará atuando, permanentemente, em todos os lugares onde os brasileiros moram e trabalham, e não somente nos Poderes Executivo e Legislativo. É uma organizaçâo que vincula os movimentos sociais e reivindicatórios à vida política sem tutelá-los (PROGRAMA DO PMDB, 1996, p. 48).

O partido exerce a função de representação e seus membros calculam as suas estratégias para ganhar votos a partir dos elementos presentes no sistema eleitoral. No que diz respeito à natureza do mandato - se livre ou imperativo, o programa afirma que "o instituto da fidelidade partidária é questão de princípio para o PMDB. O mandato eleitoral deve pertencer ao partido, perdendo-o quem o deixar ou dele for expulso em decorrência de violaçóes Programa Doutrinário e aos Estatutos" (PROGRAMA DO PMDB, 1996, p. 52). A posição do PMDB é a de que o mandato pertence ao partido. Uma posição contrária seria a de um "mandato livre", qual seja a de que a representação pertence ao parlamentar, em desacordo com o conteúdo da carta programática. Em relação ao sistema eleitoral, apoia o formato misto: “o PMDB dará seu apoio à adoção do sistema eleitoral misto, que combinar em proporçóes adequadas o sistema distrital majoritário com o sistema proporcional.".

Aspecto importante levantado nos estudos sobre disparidade curvilinear, sobretudo nos testes de Kennedy, Lyons e Fitzgerald (2006) é a economia. Em termos

\footnotetext{
${ }^{6}$ É interessante notar que, através de estudo de caso feito em Belo Horizonte, Telles e Storni (2011) encontraram o eleitor peemedebista com posicionamento mais autoritário que os demais eleitores.
} 
ideológicos, esta discussão diz respeito à relação Estado e mercado: a regulação da economia pelo Estado, bem como a intensidade desta intervenção. O PMDB prefere um Estado mais regulador do mercado, como pode ser observado:

Baseando-se, pois, numa visão de longo prazo, o PMDB não se deixa impressionar pela miragem do fim da soberania, mas procura entender sua verdadeira expressão nas novas condiçôes tecnológicas. Aliás, o sistema mundial de Estados Nação é fruto da globalização do capitalismo. Em todas as naçóes bem sucedidas, o Estado tem sido o grande instrumento regulador das atividades econômicas, estando à chave do sucesso na combinação de um máximo de competição com um máximo de planejamento (Programa do PMDB, 1996, p. 58).

A política governamental também é aspecto importante para configurar ideologia, pois diz respeito aos países parceiros com os quais os Estados estabelecem relações preferenciais. Foi selecionada a questão das relações internacionais, - a posição do governo brasileiro no MERCOSUL, Parlamento da UNASUL - e questóes relativas à conjuntura política, tais como caso Honduras, que contou com a intervenção do Brasil, bem como a presença de tropas nacionais no Haiti etc. Uma maior disposição à atuação brasileira no exterior indicaria uma adequação maior às ideias expressas no programa:

4.1.3 - O PMDB considera indispensável à ativa e enérgica presença do Brasil na ONU, no GATT, no FMI, no Banco Mundial e outras agências internacionais, no Parlamento Latino-Americano, no Mercosul, no Pacto Amazônico, no Pacto Andino e em outras organizaçôes e instâncias de âmbito regional buscando, acima de tudo, a solução negociada das questôes internacionais e bilaterais. Mas estará permanentemente pronto a defrontar-se com as dificuldades que se anteponham ao seu projeto nacional, solidarizando-se com a luta similar de outros países.

4.1.4 - O Brasil deverá relacionar-se com os Estados Unidos, com os países que integram a Comunidade Europeia, o Japão, a China, buscando concretizar todas as possibilidades de cooperação e intercâmbio comercial, cultural e técnico. Ao mesmo tempo, o Brasil se posicionará contra deliberaçóes destes e de outros países que possam significar excessos na defesa de interesses hegemônicos, medidas protecionistas ou discriminatórias. (PROGRAMA DO PMDB, 1996, p. 66).

Em relação aos valores - se mais tradicionais ou seculares -, foi utilizada a posição do PMDB sobre a aplicaçáo da pena de morte, uma vez que temas como 
aborto e união civil entre pessoas do mesmo sexo, variáveis mais clássicas para indicar valores, não são tratadas pelo partido: "o PMDB é intransigentemente a favor da vida e, por isso, tem posição firmada contra a pena de morte” (Programa do PMDB, 1996, p. 48). Tendo em vista a posição do partido expressa, o consentimento com tal pena revelaria uma discordância com o estabelecido no programa.

\section{Lideranças e Eleitores: survey}

Para estudar as atitudes dos líderes partidários, o universo pesquisado foi definido como os membros da Executiva Municipal de Belo Horizonte. Foi entrevistado o total da sua população - sete dirigentes. Em seguida, suas opinióes foram contrastadas com a dos eleitores, a partir dos dados fornecidos pela pesquisa BH Barômetro (GRUPO OPINIÃO PÚBLICA e IPESPE, 2008). filtrando os eleitores que se identificam com o PMDB. Em caso da Lei da Disparidade estar correta, tem-se a expectativa que os líderes expressem posiçóes semelhantes aos dos eleitores.

Os líderes entrevistados eram membros da Executiva Municipal do PMDB que estavam exercendo o seu mandato durante as eleiçóes municipais de 2008. Este Diretório Municipal foi constituído no dia 23/10/2005 e com vencimento em 27/10/2009 (mandato de quatro anos). A Executiva era composta por 45 membros efetivos, 15 membros suplentes, e destes sete compunham a Executiva (Presidente, $1^{\circ}$ Vice-Presidente, 2o Vice- Presidente ${ }^{7}$, Secretário(a) Geral, Secretário(a) Adjunto(a), Tesoureiro(a), Vogais). A maior parte dos questionários foi aplicada na segunda quinzena de 2009, de forma vis-à-vis; as entrevistas faltosas foram realizadas durante o primeiro semestre de $2010^{8}$. A partir daí, as respostas de cada indivíduo entrevistado foi codificada de forma padronizada e registrada de forma quantitativa.

Em relação à opinião dos eleitores, os dados foram coletados em dois survey, no $1^{\circ}$ e no $2^{\circ}$ turno das eleições municipais de Belo Horizonte (2008). As entrevistas foram feitas com 800 eleitores, maiores de 18 anos e com cota de regiáo, idade e sexo. A data de realização das coletas de dados foi entre os dias 23 e 27 de setembro de 2008, $1^{\circ}$ turno, e 19 e 22 de outubro de $2008,2^{\circ}$ turno. O tamanho do erro amostral de cada survey foi de 3,1 pontos percentuais.

$O$ survey é apenas um tipo particular de pesquisa social empírica, mas há muitos tipos de pesquisas, que incluem censos demográficos, pesquisas de opinião,

\footnotetext{
${ }^{7}$ Um dos vice-presidentes saiu do partido antes da aplicação do questionário, não sendo substituído devido à necessidade da eleição de um novo diretório.

${ }^{8}$ Para ver o questionário completo que foi aplicado aos componentes da executiva consultar os anexos. Apresento abaixo apenas as questóes que acredito necessitarem de um maior detalhamento.
} 
estudos acadêmicos, que podem ter seus desenhos alterados devido a diferentes objetivos, custos e tempo. Babbie (1999) ressalta que "há três objetivos gerais permeiam todos estes interesses: descrição, explicação e exploração" (BABBIE, 1999, p. 95). Um survey pode visar (e usualmente visa) atingir mais de um destes objetivos; acredita-se que todos os três objetivos citados foram contemplados no desenho do presente trabalho. Buscou-se descrever o perfil dos entrevistados, fazer asserçóes explicativas a respeito do alinhamento com o programa partidário, explorar a simetria entre o pensamento dos líderes partidários com os eleitores identificados com o partido.

O primeiro bloco do questionário foi constituído de perguntas sóciodemográficas - sexo, renda e escolaridade - e perguntas especificas sobre o(a) membro do partido - se já foi filiado a outro partido, o tempo de filiação ao atual partido, se já ocupou cargos de confiança em alguma esfera governativa, se já foi candidato a algum cargo eletivo (sendo eleito ou não) e se já participou ou participa de alguma corrente interna do partido.

Em seguida, foram realizados alguns blocos com base nos dados levantados na pesquisa documental, para averiguar o conhecimento e a adequação do entrevistado à carta programática. A primeira condicionante testada, como apresentado acima, foi sobre a quem pertence o mandato do candidato eleito pelo partido. ${ }^{9}$ A segunda, sobre qual sistema eleitoral seria o mais próximo daquele defendido pelo partido ${ }^{10}$. Outra pergunta se refere à opiniáo do líder sobre a intervenção do Estado na economia nacional $^{11}$. A quarta pergunta verifica como o partido deve se posicionar na relação a outros países e com os órgãos internacionais ${ }^{12}$. E finalmente, averigua-se a opinião do entrevistado sobre a adoção da pena de morte no Brasil ${ }^{13}$.

\footnotetext{
9 "Na opinião do (a) Sr. (a) a quem deve pertencer o mandato eleitoral (?): 1) Ao partido; 2) Ao deputado; 3) Ao candidato e Ao partido; 88) NS; 99) NR."

10 "Na opiniấo do (a) Sr. (a), qual destes sistemas de listas eleitorais é o MELHOR (?): 1) O sistema Majoritário; 2) O sistema Proporcional; 3) O sistema Misto; 4) Outro. Qual?”

11 "Das seguintes frases que eu vou citar, com qual delas o (a) Sr. (a) MAIS se identifica? 1) 'É função de o Estado intervir na economia regulando a produção e o comércio de bens e serviços'; 2) 'É função de o Estado garantir o funcionamento do mercado, intervindo apenas em casos de crise'; 3) 'É função de o Estado dar total liberdade ao mercado sem intervir em seu funcionamento de qualquer forma'; 88) NS; 99) NR."

12 "Com relação ao papel do Brasil na sua relação com demais países e órgãos internacionais, com qual destas frases o (a) Sr. (a) MAIS se identifica? 1) 'O Brasil deve se posicionar ativamente nas instâncias de negociação internacional, promovendo seus interesses e buscando aumentar sua influência junto a outros países'; 2) 'O Brasil deve adotar uma postura neutra sem interferir nas questôes de outros países ou se posicionar com relaçóes às questóes internacionais'; 3) 'O Brasil deve se apenas reagir e se
} 
Outro bloco do questionário caracteriza o partido como de "quadro" ou de "massa" segundo os entrevistados. Para isso, foram elaboradas cinco questôes ${ }^{14}$, que possibilitam a verificaçáo do afirmado pelo programa do partido: o PMDB é um partido de massa. Os próximos outro quatro blocos do questionário têm relação com o questionário do BH Barômetro (GRUPO OPINIÁO PÚBLICA e IPESPE, 2008). Reaplicamos as mesmas perguntas que foram feitas aos eleitores, para que pudéssemos comparar as respostas e verificar a presença ou ausência de similaridades de opinióes entre os líderes e os eleitores do PMDB.

Os blocos semelhantes, aplicados para os líderes e os eleitores foram os seguintes: o primeiro bloco trata do associativismo - se já participaram de algum movimento (sindical, estudantil, religioso ou de bairro). O segundo bloco busca compreender a percepção política dos entrevistados e as suas concepçôes ideológicas. Foi solicitado que os entrevistados caracterizassem uma série de partidos e indicassem seu posicionamento ideológico. Esse bloco é seguido pelo bloco denominado "representação política", que visava compreender quais os motivos que deveriam guiar um candidato quando se lança na arena eleitoral. O próximo bloco buscava averiguar o nível de confiança dos entrevistados nas instituições políticas e interpessoal, seguido pela avaliação do grau de adesão dos mesmos aos processos democráticos e a sua satisfação com a atual situação da democracia brasileira. E, finalmente, solicitou-se que os entrevistados atribuíssem notas aos ocupantes dos três cargos executivos daquela ocasiáo: o Presidente Lula da Silva, o Governador (atualmente ex-governador) Aécio Neves e o Prefeito (atual ex-prefeito) Fernando Pimentel.

posicionar com relação a questôes internacionais somente quando acionado por outros países ou órgãos internacionais'; 88) NS; 99) NR.”

13 "Continuando, agora gostaria que o (a) Sr. (a) me dissesse se concorda ou discorda da pena de morte: 1) Concorda, 1.a) Totalmente, 1.b) Em Parte; 2) Discorda, 2.a) Totalmente, 2.b) Em Parte; 88) NS; 99) NR."

14 "Agora vamos mudar um pouco de assunto. Entre os pares de frases abaixo, por favor, indique qual se aproxima mais da sua maneira de pensar: $1^{\text {a }}$ dupla de respostas $(1$. O partido deve ser financiado principalmente por seus filiados; 2 . O partido deve buscar financiamento principalmente de fontes externas); $2^{\mathrm{a}}$ (1. O partido deve ser fiel aos seus princípios e objetivos, mesmo se esta atitude o fizer perder votos; 2. O partido deve tratar, acima de tudo, de conseguir o maior número possível de votos); $3^{\text {a }}$ (1. As decisões partidárias devem ser tomadas pela executiva municipal do partido; 2. As decisóes partidárias devem ser tomadas com grande participação das bases do partido); 4a (1. O mandato parlamentar deve sempre seguir as orientaçôes de seu partido; 2. O parlamentar deve ter autonomia para atuar durante seu mandato); 5a (1. O partido deve estabelecer alguns critérios para receber novas filiaçốes; 2. A filiação ao partido deve ser aberta a todos os indivíduos).” 
Como mecanismo de comparação, utilizamos as médias das respostas, dado que

as opiniôes individuais se localizem num continuum e que a expressão estatística das opinióes de todos os membros do grupo - a moda, o meio, a média, a mediana - sejam vistas como as opinióes preponderantes ou "centro de gravidade" do grupo (MAY, 1973, p. 136, tradução livre).

Por isso, consideramos a média um bom preditor para a comparação da opiniáo desses dois grupos.

\section{Resultados: Ideologia e opiniões dos eleitores e lideres do PMDB}

O segundo ponto é o universo de eleitores que usaremos como base de comparação para esse estudo. Como ressaltamos, usaremos os dados do $\mathrm{BH}$ Barômetro (GRUPO OPINIÁO PÚBLICA e IPESPE, 2008) como a fonte de dados das opinióes dos eleitores, mas precisamente apenas a $1^{\circ}$ rodada, que foi aplicado no $1^{\circ}$ turno das eleiçóes. Com acesso ao banco, realizamos um recorte utilizando as opiniôes apenas dos eleitores identificados com PMDB. Estes eleitores representam 9,5\% dos entrevistados ${ }^{15}$ identificados com o partido.

$15 \mathrm{O}$ número de eleitores identificados com o PMDB em Belo Horizonte não permite análise multivariada. 
Gráfico 1 - Preferência por Partido Político ( $1^{\circ}$ e $2^{\circ}$ turnos), Belo Horizonte 2008

\section{Identidade Partidária em Belo Horizonte (2008)}

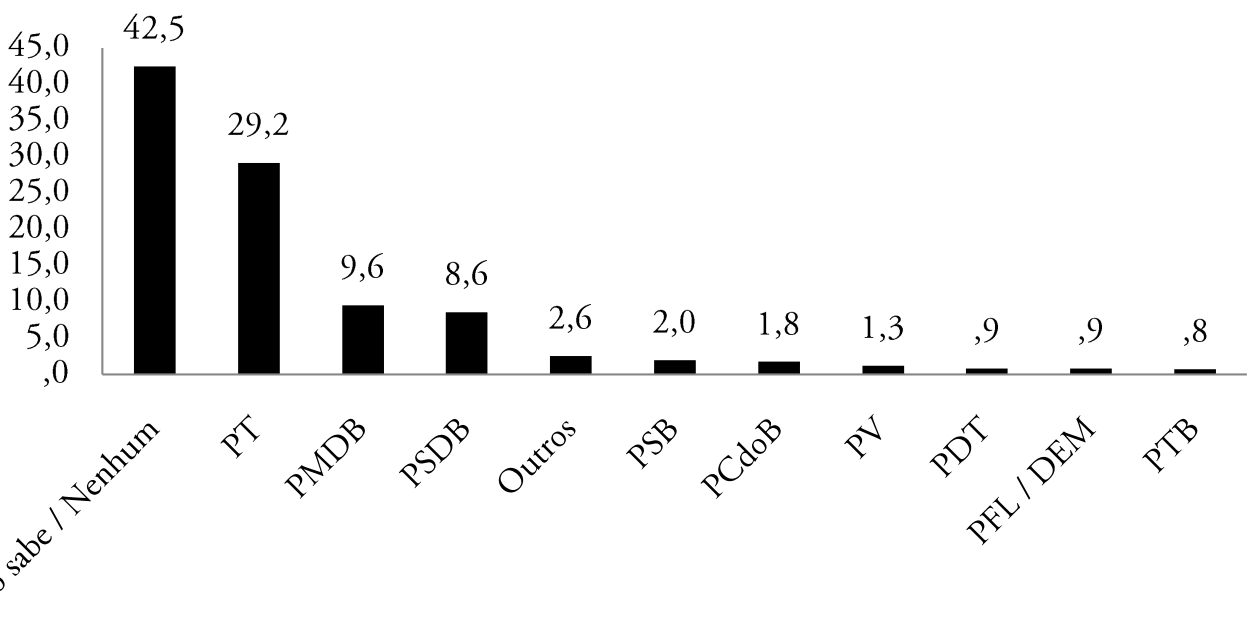

Fonte: GRUPO OPINIÃO PÚBLICA e IPESPE (2008).

Observa-se nos Gráficos 1 e 2 as preferências por partidos na cidade de Belo Horizonte. Nota-se que o PT era o partido preferido e um alto percentual $(42,5 \%)$ dos eleitores não possuía preferências partidárias. Contudo, se são analisados apenas os eleitores que possuem identidade com algum partido, 16,7\% destes se identificam com o PMDB, resultado apenas menor que o percentual de identificados com o PT. 
Gráfico 2 - Preferência por Partido Político ( $1^{\circ}$ e $2^{\circ}$ turnos $)$ entre eleitores que têm preferência partidária - Belo Horizonte 2008

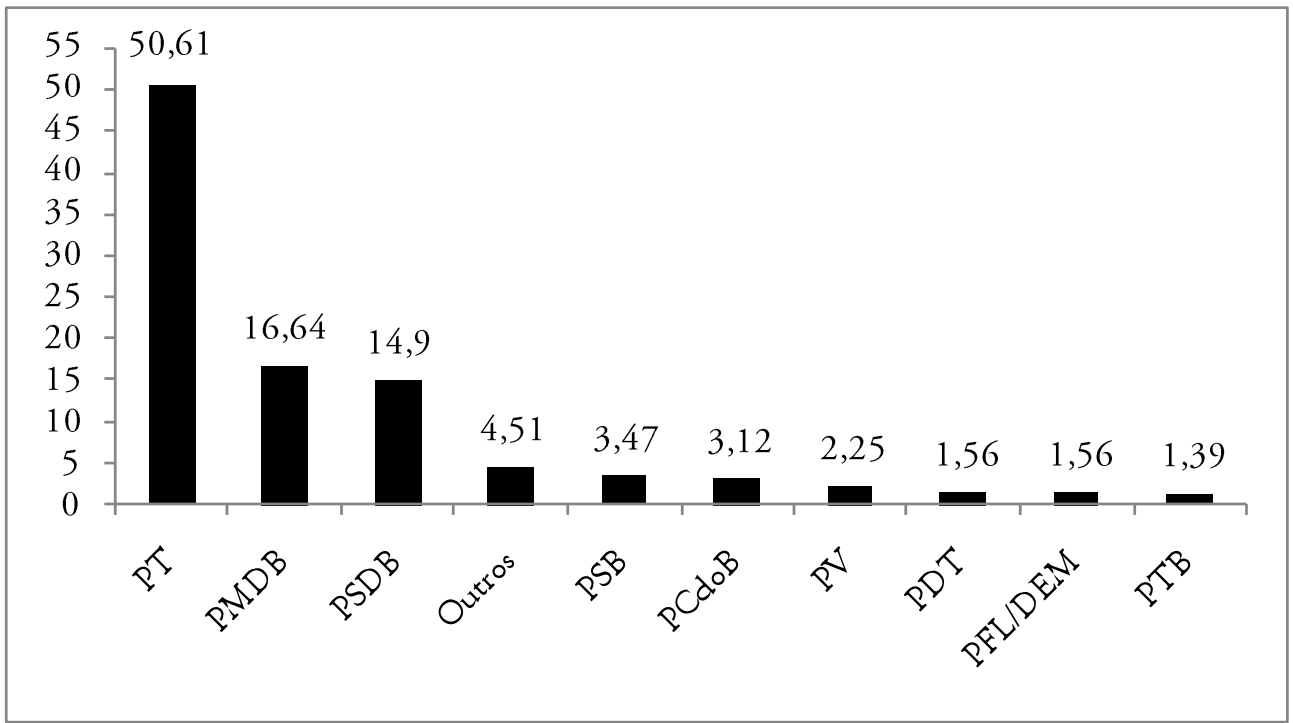

Fonte: Pesquisa com Lideranças do PMDB realizada pelos autores em 2008; GRUPO OPINIÃO PÚBLICA e IPESPE (2008). Foram excluídos os partidos que não alcançaram 1\% de identificação.

Apresentado o quadro geral dos eleitores que se identificam com partidos políticos em Belo Horizonte, passaremos aos dados sócio-demográficos dos membros da Executiva Municipal do PMDB e dos eleitores identificados com o partido (peemedebistas) durante as eleições municipais de 2008. 
Tabela 1 - Dados Sócio-demográficos das Lideranças e dos Eleitores do PMDB (\%)

\begin{tabular}{|c|c|c|c|}
\hline & & Lideranças & Eleitores \\
\hline \multirow{2}{*}{ Sexo } & Masculino & 71,4 & 40,0 \\
\hline & Feminino & 28,6 & 60,0 \\
\hline \multirow{4}{*}{ Idade } & 16 a 17 anos & 0 & 1 \\
\hline & 18 a 24 anos & 0 & 17,10 \\
\hline & 25 a 49 anos & 85,7 & 57 \\
\hline & 50 anos ou mais & 14,3 & 25 \\
\hline \multirow{5}{*}{ Escolaridade } & Sem escolaridade a primário incompleto & 0 & 2,6 \\
\hline & Primário completo a Ginasial completo & 0 & 25,0 \\
\hline & Ginasial Completo a Ensino Médio Incompleto & 0 & 19,7 \\
\hline & Ensino Médio Completo & 14,3 & 40,8 \\
\hline & Superior incompleto a Pós Graduação & 85,7 & 11,8 \\
\hline \multirow{3}{*}{ Classe Social } & A & 28,5 & 13,4 \\
\hline & B & 57 & 39,6 \\
\hline & $\mathrm{C} / \mathrm{D}$ & 14,5 & 47 \\
\hline
\end{tabular}

Fonte: Pesquisa com Lideranças do PMDB realizada pelos autores em 2008; GRUPO OPINIÃO PÚBLICA e IPESPE (2008).

Os dados sócio-demográficos já apresentam pontos de semelhança e de dissonância entre os dois grupos aqui analisados. Enquanto a maioria das lideranças é composta por pessoas do sexo masculino, os eleitores peemedebistas são majoritariamente do sexo feminino. A próxima variável diz respeito à divisão por classe social dos entrevistados. A maioria dos líderes está entre a classe A e B, ao passo que os eleitores estáo colocados entre as classes B, C e D.

No entanto, se nos retivermos à idade e escolaridade, os dados apresentam algumas semelhanças já que maior parte dos entrevistados possui idade superior a 25 anos e escolaridade acima do ensino médio completo. Analisados os dados separadamente, eles podem nos apresentar uma boa descrição dos entrevistados, mas ao serem comparados com a teoria, observamos que os pontos de alinhamento são explicáveis. A teoria para o eleitorado brasileiro indica que os eleitores que seriam mais identificados com partidos políticos seriam os de maior escolaridade (CARREIRÃO e KINZO, 2004). No entanto, o eleitorado peemedebista se distribui igualmente entre alto e baixo nível de escolaridade - até colegial e em seguida, ensino médio completo e universitário. Em relação ao alto percentual de simpatizantes com idade superior a 50 anos (25\%), o fator explicativo pode se encontrar pela lembrança do passado do MDB, como sendo o partido de oposição ao regime ditatorial. 
Após estes dados, apresentaremos algumas características especificas dos membros da executiva municipal do PMDB. Estas características servirão de guia para uma melhor compreensão das análises de similaridades que traçaremos em sequencia.

Tabela 2 - Tipologia das lideranças

\begin{tabular}{c|c}
\hline Características & $\mathbf{\%}$ \\
\hline Tempo de Filiação & 14,3 \\
\hline Anterior à fundação como partido & 85,7 \\
\hline Já como PMDB & 100,0 \\
\hline Participação em corrente interna & 0,0 \\
\hline Sim & \\
\hline Não & 14,3 \\
\hline Filiação a outro partido & 85,7 \\
\hline Sim & 71,4 \\
\hline Não & 28,6 \\
\hline Já ocupou cargo de confiança pelo partido & \\
\hline Sim & 85,7 \\
\hline Não & 14,3 \\
\hline Já foi candidato a algum cargo eletivo &
\end{tabular}

Fonte: Pesquisa com Lideranças do PMDB realizada pelos autores em 2008.

Os cinco pontos destacados na Tabela 2 são de grande relevância na caracterização das lideranças do partido. Com esses dados, podemos perceber que a maioria dos ocupantes dos cargos da Executiva Municipal do PMDB, em Belo Horizonte, é formada por indivíduos que já disputaram cargos eletivos $(85,7 \%)$, nunca foram filiados a outro partido político (85,7\%), participaram de alguma corrente interna dentro do partido (100\%), já ocuparam cargos de confiança indicados pelos partidos (71,4\%) e se filiaram ao PMDB após 1980 (85,7\%), quando o sistema político brasileiro já estava de volta ao pluripartidarismo.

Essas características somadas colocam algumas expectativas: os membros da Executiva Municipal devem conhecer o programa do partido nos quais são dirigentes e, por isso, devem concordar com o seu programa estratégico e eleitoral, pois nunca se desfilaram ou foram filiados algum outro partido. 
Ao mesmo tempo, outra expectativa é a de que os líderes devem apresentar um pensamento não muito distante dos eleitores, dado que possuem experiência na arena eleitoral e já ocuparam cargos de confiança pelo partido. Estas duas variáveis experiência, sobretudo no PMDB, e participação em eleições - indicam que devemos encontrar lideranças partidárias alinhadas com o programa do PMDB, mas ao mesmo tempo, com o seu eleitor.

Para esse teste, comparamos a executiva do PMDB em Belo Horizonte e os eleitores identificados com o partido. Com a análise dos dados a seguir podemos verificar a proximidade ou náo das opinióes dos eleitores e lideranças do PMDB em Belo Horizonte. Apresentaremos primeiramente a comparação das opinióes dos eleitores e lideranças quanto à avaliação da administração dos atuais governantes, a percepção sobre os partidos políticos e a confiança nas instituiçóes democráticas.

As primeiras opinióes dizem respeito a como os entrevistados avaliavam os governos de Lula, Aécio Neves e Fernando Pimentel. A pergunta foi "Agora eu gostaria que o(a) senhor(a) avaliasse as seguintes administraçóes como péssimo, ruim, regular, bom ou ótimo". As avaliaçóes foram depois recodificadas ${ }^{16}$ em forma de variáveis quantitativas (notas), sendo que a maior nota possível era cinco (ótimo) e a menor nota era um (péssimo). Apresentamos o Gráfico 3 com os dados da comparação:

\footnotetext{
${ }^{16}$ Para cada resposta foi atribuída uma nota: 5 - ótimo; 4 - bom; 3 - regular; 2 - ruim; 1 - péssimo. Por isso temos a variação das notas entre cinco e um.
} 
Gráfico 3 - Média da avaliação das Administrações - Governo Federal, Governo Estadual e Governo Municipal

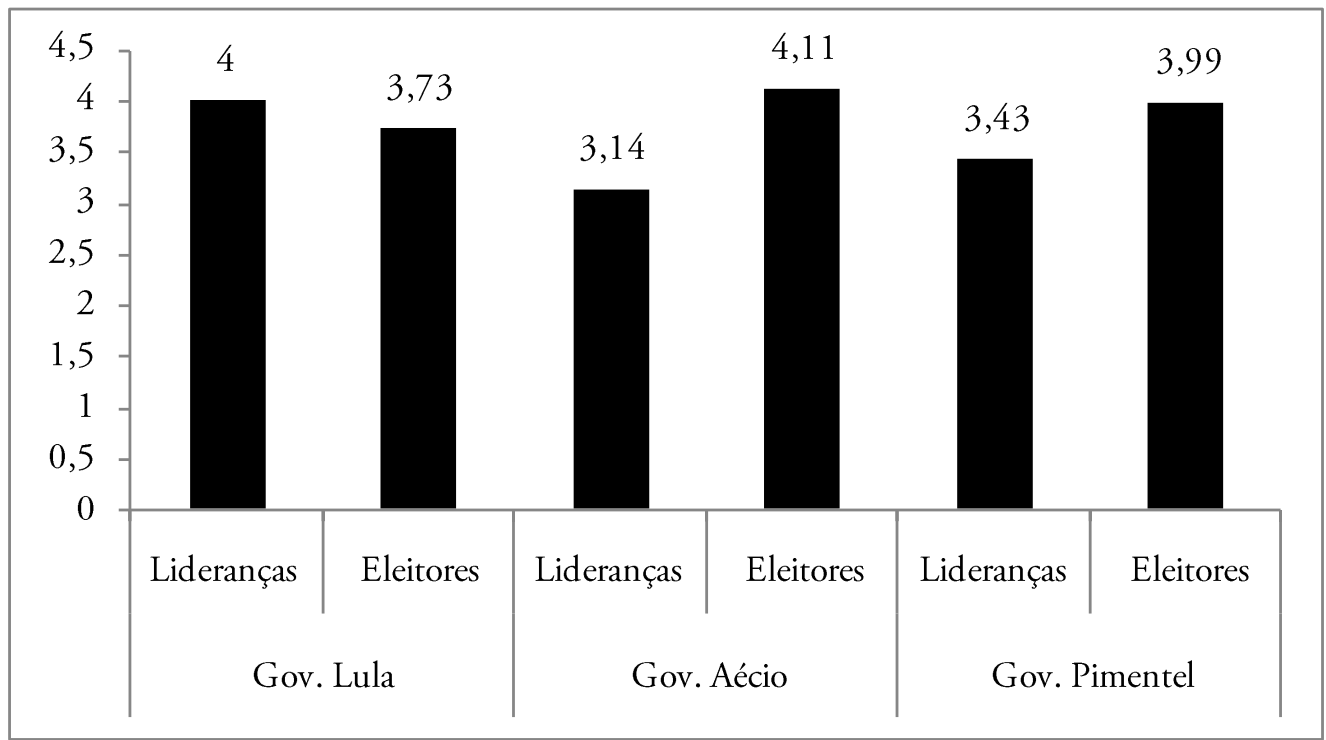

Fonte: Pesquisa com Lideranças do PMDB realizada pelos autores em 2008; GRUPO OPINIÃO PÚBLICA e IPESPE (2008).

Todas as avaliaçóes, tanto das lideranças como dos eleitores, foram positivas para todos os governos pesquisados. Em relação ao governo de Lula da Silva, a avaliação média das lideranças foi maior que a dos eleitores, o que pode ser interpretado pelo fato de o PMDB fazer parte da base aliada do governo federal desde o segundo mandato de Lula da Silva, em 2006. Esse fato pode explicar a boa avaliação feita pela executiva do PMDB, uma vez que avaliá-lo negativamente significaria, de certa forma, avaliar negativamente também sua própria participação na base do governo.

Já a avaliação feita do então governo do Estado (Aécio Neves), é a melhor entre os eleitores e a menor segundo as lideranças partidárias. Ressaltamos apenas que a avaliação dos eleitores é um reflexo da enorme popularidade do ex-governador (90\%) pela população mineira e, mais ainda, entre os belo-horizontinos. No entanto, a executiva do PMDB não mostrou toda essa certeza sobre a eficiência do governo de Aécio Neves. Percebe-se aqui uma contradição entre os posicionamentos dos líderes do PMDB e o dos eleitores, o que pode ser explicado pelo fato do partido se assumir no plano estadual como oposição ao governo estadual.

Quanto a ex-prefeito Fernando Pimentel, este igualmente tinha avaliação positiva sobre o seu desempenho na prefeitura. Os líderes do PMDB avaliam sua administração com nota superior ao do ex-presidente Lula da Silva. Em relação às 
lideranças peemedebistas, é necessária uma digressão explicativa. É sabido que o PMDB optou por, em 2008, disputar a prefeitura de Belo Horizonte de forma autônoma, sem se coligar com o PT e o Partido Socialista Brasileiro (PSB), que lançaram o candidato Márcio Lacerda (PSB). No entanto, não houve momento algum na campanha de Leonardo Quintáo (candidato peemedebista), em que ele tenha se posicionado como oposição ao governo de Fernando Pimentel. Muito pelo contrário, o candidato do PMDB fez questão de enaltecer os mandatos do ex-prefeito e de garantir que faria um trabalho de continuidade em relação ao que já havia sido iniciado por Fernando Pimentel. Por esta razão, as notas das lideranças do PMDB refletem essa situação ambígua. Deste modo, nota-se proximidade entre os eleitores e os dirigentes municipais do PMDB, dado que as avaliaçóes dos governos coincidem no fato de serem positivas.

Em sequencia, compara-se a opinião dos eleitores e lideranças. Serão expostas as percepçôes e as classificaçóes ideológicas dos partidos políticos - PMDB, PSDB, PT, PFL/Democratas (DEM), PSB, Partido Comunista do Brasil (PC do B) e PDT segundo algumas características.

Tabela 3 - Percepção dos partidos políticos quanto a sua posição ideológica pelas lideranças e eleitores do PMDB em Belo Horizonte (\%)

\begin{tabular}{|c|c|c|c|c|c|c|c|c|c|c|}
\hline & & \multicolumn{9}{|c|}{ Partidos } \\
\hline & & PMDB & PSDB & PT & $\begin{array}{l}\text { PFL/ } \\
\text { DEM }\end{array}$ & PSB & $\begin{array}{l}\text { PC do } \\
\text { B }\end{array}$ & PDT & Todos & Nenhum \\
\hline \multirow{2}{*}{$\begin{array}{c}\text { Defende mais } \\
\text { os ricos }\end{array}$} & Lideranças & 0 & 57,1 & 0 & 42,9 & 0 & 0 & 0 & 0 & 0 \\
\hline & Eleitores & 7,1 & 26,6 & 11,8 & 19,2 & 0 & 1,3 & 3,9 & 13,2 & 1,3 \\
\hline \multirow{2}{*}{$\begin{array}{l}\text { Defende mais } \\
\text { os pobres }\end{array}$} & Lideranças & 57,1 & 0 & 28,6 & 0 & 0 & 0 & 0 & 0 & 14,3 \\
\hline & Eleitores & 4,4 & 10,3 & 41,2 & 0 & 0 & 7,4 & 2,9 & 0 & 25 \\
\hline \multirow{2}{*}{$\begin{array}{c}\text { É o mais de } \\
\text { esquerda }\end{array}$} & Lideranças & 0 & 0 & 28,6 & 0 & 0 & 71,4 & 0 & 0 & 0 \\
\hline & Eleitores & 5,3 & 3,9 & 26,3 & 1,3 & 5,3 & 15,8 & 2,6 & 1,3 & 0 \\
\hline \multirow{2}{*}{$\begin{array}{c}\text { É o mais de } \\
\text { direita }\end{array}$} & Lideranças & 0 & 28,6 & 0 & 71,4 & 0 & 0 & 0 & 0 & 0 \\
\hline & Eleitores & 28,9 & 18,4 & 9,2 & 1,3 & 3,9 & 3,9 & 1,3 & 0 & 0 \\
\hline
\end{tabular}

Fonte: Pesquisa com Lideranças do PMDB realizada pelos autores em 2008; GRUPO OPINIÃO PÚBLICA e IPESPE (2008).

Quando perguntados sobre qual partido defende os mais ricos, os líderes do PMDB se dividiram entre a escolha do PSDB $(57,1 \%)$ e do DEM (42,9\%), com uma vantagem do primeiro em relação ao segundo. Existe certa coerência nessa 
escolha, pois, tendo seus quadros amplamente constituídos por empresários, profissionais liberais e grandes agricultores, estes dois partidos possuem uma imagem elitista perante a sociedade brasileira. O eleitorado peemedebista, por sua vez, optou em primeiro lugar pelo PSDB: 26,6\% deste eleitorado considera que o PSDB é o partido que defende os mais ricos. Em seguida temos, em relação a esta variável, de acordo com a opiniáo expressa pelo eleitor: o PMDB (17,1\%), PT (11,8\%) e o DEM $(9,2 \%)$. Note-se que a primeira escolha coincidiu em ambos os estratos - líderes e eleitores - no qual o PSDB é considerado como partido que mais defende os mais ricos.

Com relação à opinião sobre o partido que mais defende mais os mais pobres, dois líderes optaram pelo próprio PMDB, dois outros pelo PT e um por nenhum. A opção pelo PT parece se justificar na medida em que o governo Lula da Silva é marcado por um forte discurso e por políticas de auxílio à parcela mais pobre da população brasileira, ademais a história deste partido é fundamentada sob valores socialistas, o que o classifica como um partido comprometido com a promoçáo da igualdade social. Tal imagem é corroborada pelos eleitores peemedebistas: quase 39\% deles indicaram o PT como partido que mais defende os mais pobres, em seguida o PMDB e o PCdoB, com 22,4\% e 15,8\%, respectivamente. Ambas as opçôes também são coerentes: no primeiro caso, porque se trata do próprio partido em que votam, e tende-se a ser mais simpático com partidos que apoiam os mais pobres; no segundo caso, por se tratar também de um partido de esquerda que, em Belo Horizonte, conseguiu firmar uma imagem, sobretudo pelo apoio declarado por Jô Morais, candidata pelo PC do B, em 2008, no segundo turno, junto com parcelas insatisfeitas do PT, que apoiaram o candidato do PMDB. Estas duas variáveis apresentam uma coincidência razoável entre as opinióes de eleitores e líderes do PMDB.

Quanto à classificação dos partidos como de esquerda e direita, as lideranças tem uma opinião clara sobre quais partidos classificar - PFL/DEM como de direita e PC do B como de esquerda. Os eleitores têm uma percepção mais dispersa desta classificação ${ }^{17}$, como pode ser observado na Tabela 4 .

${ }^{17}$ Em artigo recente, Telles e Storni (2011) discutem a percepção da escala ideológica pelo eleitorado. 
Tabela 4 - Percepção dos partidos políticos quanto a sua atuação política pelas lideranças e eleitores do PMDB em Belo Horizonte (\%)

\begin{tabular}{|c|c|c|c|c|c|c|c|c|c|c|}
\hline & & \multicolumn{9}{|c|}{ Partidos } \\
\hline & & PMDB & PSDB & PT & $\begin{array}{l}\text { PFL/ } \\
\text { DEM }\end{array}$ & PSB & $\begin{array}{c}\text { PC do } \\
\text { B }\end{array}$ & PDT & Todos & Nenhum \\
\hline \multirow{2}{*}{$\begin{array}{l}\text { Tem mais } \\
\text { políticos } \\
\text { honestos }\end{array}$} & Lideranças & 42,9 & 0 & 0 & 0 & 0 & 42,9 & 0 & 0 & 14,3 \\
\hline & Eleitores & 42,1 & 6,6 & 2,6 & 1,3 & 1,3 & 2,6 & 1,3 & 0 & 34,2 \\
\hline \multirow{2}{*}{$\begin{array}{l}\text { Tem mais } \\
\text { políticos } \\
\text { corruptos }\end{array}$} & Lideranças & 0 & 14,3 & 28,6 & 42,9 & 0 & 0 & 0 & 14,3 & 0 \\
\hline & Eleitores & 7,9 & 13,2 & 21,1 & 6,6 & 3,9 & 2,6 & 0 & 31,6 & 0 \\
\hline \multirow{2}{*}{$\begin{array}{c}\text { Administra } \\
\text { melhor o país, } \\
\text { os estados ou as } \\
\text { cidades }\end{array}$} & Lideranças & 71,4 & 0 & 28,6 & 0 & 0 & 0 & 0 & 0 & 0 \\
\hline & Eleitores & 39,5 & 13,2 & 21,1 & 2,6 & 0 & 5,3 & 0 & 0 & 6,6 \\
\hline \multirow{2}{*}{$\begin{array}{c}\text { É mais aberto à } \\
\text { participaçáo } \\
\text { da populaçáo }\end{array}$} & Lideranças & 100 & 0 & 0 & 0 & 0 & 0 & 0 & 0 & 0 \\
\hline & Eleitores & 25 & 2,6 & 36,8 & 1,3 & 5,3 & 10,5 & 1,3 & 0 & 0 \\
\hline
\end{tabular}

Fonte: Pesquisa com Lideranças do PMDB realizada pelos autores em 2008; GRUPO OPINIÃO PÜBLICA e IPESPE (2008).

Em relação à opinião sobre qual partido tem mais políticos honestos, tivemos a resposta esperada. Por parte dos eleitores, estes consideram o PMDB como o mais honesto $(42,1 \%)$. Em relação aos líderes, chama atenção o fato de não ter ocorrido unanimidade na escolha do próprio partido, já que dois partidos que foram alocados como o mais honesto (42,9\%): PMDB e PCdoB. Perguntados sobre quem administra melhor a cidade, o estado ou o país, o pensamento entre lideranças e eleitores se assemelha, pois os líderes identificam o PMDB $(71,4 \%)$ e os eleitores também (39,5\%), embora a diferença entre estes estratos seja significativa. Por último, temos a opinião sobre qual partido seria mais aberto à participação. Toda a Executiva Municipal acredita ser o PMDB e os eleitores consideram o PT como o mais aberto (36,8\%), seguido pelo PMDB (25\%).

Foi solicitado aos líderes e aos eleitores que dessem nota para a confiança nas seguintes instituições: partidos políticos, Câmara dos Deputados, imprensa, TV, ONGs, empresas privadas e Igrejas. 
Tabela 5 - Confiança nas Instituições (nota média) ${ }^{18}$

\begin{tabular}{c|c|c}
\hline & Lideranças & Eleitores \\
\hline Partidos Políticos & 4,86 & 3,96 \\
\hline Câmara dos Deputados & 5,00 & 3,45 \\
\hline Imprensa & 4,14 & 5,49 \\
\hline TV & 3,14 & 5,76 \\
\hline ONGs & 5,86 & 4,83 \\
\hline Empresas privadas & 4,29 & 4,89 \\
\hline Igreja & 5,71 & 6,21 \\
\hline
\end{tabular}

Fonte: Pesquisa com Lideranças do PMDB realizada pelos autores em 2008; GRUPO OPINIÃO PÚBLICA e IPESPE (2008).

Ao observar a média da confiança nas instituições por parte dos eleitores e das lideranças, nota-se que os líderes partidários confiam mais nos partidos políticos do que seus eleitores, o que pode ser explicado por fazerem parte dessa instituição e justifica a confiança na Câmara dos Deputados. Em relaçáo à imprensa e à TV, os eleitores mostraram maior confiança. A menor confiança por parte dos lideres na imprensa pode ser explicado pelo fato dos líderes partidários serem "investigados"/ "denunciados" por essas instituições. No geral, as lideranças confiam mais nas ONGs, enquanto os dois segmentos se apresentam bastante confiança na Igreja. De qualquer modo, a confiança nas instituições representativas é notavelmente baixa, inclusive entre os integrantes da Executiva Municipal.

A próxima variável é a de distribuição dos eleitores e das lideranças na escala ideológico (esquerda-direita). Esta variável é mais importante na comparação proposta neste estudo, segundo a "Lei de Disparidade Curvilinear", tomada como ponto de partida.

\footnotetext{
${ }^{18}$ Foi solicitado aos entrevistados que respondessem a seguinte questão: "Em uma escala de zero a dez, onde zero significa nenhuma confiança e dez significa confiança total, em que medida o (a) $\mathrm{Sr}$ (a) confia em cada uma destas instituiçôes ou organizaçôes." Depois foi feita a média com as respostas dos entrevistados.
} 
Tabela 6 - Autoposicionamento e posicionamento do PMDB na escala ideológica Esquerda - Direita 19

\begin{tabular}{c|c|c}
\hline & Auto Posicionamento & Posicionamento do PMDB \\
\hline Lideranças & 4,14 & 5,14 \\
\hline Eleitores & 5,66 & NSA \\
\hline
\end{tabular}

Fonte: Pesquisa com Lideranças do PMDB realizada pelos autores em 2008; GRUPO OPINIÃO PÚBLICA e IPESPE (2008).

Como apresentado na Tabela 6, na média da classificação de autoposicionamento, os líderes (média $=4,14$ ) se classificam a esquerda do eleitorado peemedebista (média $=5,66)$. E, ao mesmo tempo, os líderes classificam o próprio partido mais à direita que a sua própria opinião (média $=5,14)$, sendo esta mais próxima da média dos eleitores.

Esses dados são interessantes, já que Mendes e Santamaria (2001) encontram resultado parecido para o PSOE. As informações encontradas podem indicar que as lideranças, ao observarem a distribuição ideológica do eleitorado, percebem que este se posiciona mais ao centro (DOWNS, 1999), levando o partido a se localizar também o mais próximo possível do eleitor, já que ele necessita de votos para cumprir os seus objetivos.

Ao mesmo tempo, as lideranças se relacionam politicamente também com as suas bases intrapartidárias e, por isso, devem se posicionar mais próximos a elas. De acordo com May (1973), os militantes seriam mais ideologizados e extremistas. Todavia, para esse caso analisado, a distribuição se mostra muito próxima ao posicionamento do PMDB - partido de centro -, o que resulta em posicionamentos semelhantes entre as lideranças, os segmentos internos (militantes ou não-líderes) e externos (eleitores). Nota-se que lideranças e eleitores estáo posicionados ao centro, ainda que os líderes sejam mais radicais que os eleitores.

Finalmente, apresentam-se dados de comparação entre as opiniōes emitidas pelas lideranças e os documentos partidários. Foram aplicados aos entrevistados cinco perguntas sobre cada uma das temáticas do Programa. Para a melhor compreensão dos dados colhidos, as Tabelas 7, 8 e 9 estão formatadas da seguinte forma: das possíveis 35 respostas para cada um dos índices - características de partidos, conhecimento do programa e alinhamento com o mesmo, foi somado o número de respostas corretas e incorretas das lideranças, de acordo com o que estava em acordo com os documentos do PMDB. Os dados foram então tabulados e apresentados, de

\footnotetext{
${ }^{19}$ Foi solicitado aos eleitores e as lideranças se posicionarem na escala ideológica direita esquerda, onde a posição número um indicava extrema esquerda e a posição 10 indicava extrema direita. E para as lideranças foi solicitado que elas posicionassem o seu partido na mesma escala.
} 
forma a verificar o alinhamento entre as opiniões dos líderes partidários com as características presentes nos documentos do seu partido.

A primeira característica é quanto à tipificação do partido - quadros ou massas -, ressaltando que o PMDB se classifica formalmente como um partido de massa.

Tabela 7 - Partidos de Quadros x Massas - Lideranças PMDB

\begin{tabular}{c|c|c}
\hline & N & \% \\
\hline Respostas partidos de massa & 29 & 83 \\
\hline Respostas partidos de quadro & 6 & 17 \\
\hline Total & 35 & 100 \\
\hline
\end{tabular}

Fonte: Pesquisa com Lideranças do PMDB realizada pelos autores em 2008.

Como pode ser constatado, as lideranças estão de acordo com o que prevê o Programa do PMDB (1996), dado que a maioria das respostas (83\%) concorda com a tipificação do partido, que se assume como um "partido de massa". A segunda característica testada é quanto ao conhecimento das lideranças sobre o programa do partido.

Tabela 8 - Conhecimento do Programa - Lideranças PMDB

\begin{tabular}{c|c|c}
\hline & $\mathrm{N}$ & $\%$ \\
\hline Conhece & 28 & 80 \\
\hline Náo conhece & 7 & 20 \\
\hline Total & 35 & 100 \\
\hline
\end{tabular}

Fonte: Pesquisa com Lideranças do PMDB realizada pelos autores em 2008.

Novamente, observa-se que as lideranças possuem conhecimento sobre o atual programa do seu partido, e "acertaram" $80 \%$ do das proposições apresentadas pelo programa partidário.

Tabela 9 - Alinhamento com o Programa Partidário - Lideranças PMDB

\begin{tabular}{c|c|c}
\hline & N & \% \\
\hline Alinhado & 20 & 57,1 \\
\hline Náo alinhado & 15 & 42,9 \\
\hline Total & 35 & 100 \\
\hline
\end{tabular}

Fonte: Pesquisa com Lideranças do PMDB realizada pelos autores em 2008.

E, por último, apresenta-se o teste de alinhamento ou não do líder com o programa do seu partido. A Tabela 9 apresenta os dados mais discordantes das lideranças em relação ao Programa do PMDB (1996). No entanto, a maioria dos 
líderes $(57,1 \%)$ emite opinióes que estão em acordo com o programa do partido. Esse dado é o que nos parece mais interessante, pois indicam que, apesar de conhecerem o programa partidário, as lideranças não estão completamente de acordo com ele. No entanto, isso não os leva a deserdar - abandonar o $\mathrm{PMDB}$-, uma vez que tem grande parte de suas opinióes expressadas pelo partido que dirigem.

\section{Conclusões}

Ao analisar os dados comparativos entre eleitores e lideranças, encontramos mais pontos de sintonia do que de desvios entre as opinióes coletadas, o que nos aproxima dos estudos de May (1973). Comparando-se a média das opiniões dos entrevistados, destacamos o posicionamento ideológico como a principal ferramenta para constatar essa semelhança. Os líderes localizaram o PMDB próximo ao posicionamento médio dos eleitores, (líderes= 5,14; eleitores $=5,66$ ) o que está previsto por Downs (1999).

Deve ser ressaltado que o estudo de May (1973) foi desenvolvido com base em partidos que disputavam no interior de um sistema partidário com características específicas: sistemas bipartidários e com mecanismos de seleção de candidatos que ocorrem através de listas fechadas. Como se sabe, o legislativo brasileiro é eleito através de um sistema proporcional de listas abertas e com permissão de coligaçóes. E, há certo consenso na literatura no sentido de precisar alguns efeitos desta combinação sobre os resultados das urnas e sobre as características do corpo legislativo. Os sistemas proporcionais com listas abertas estimulam estratégias centradas nas características individuais dos candidatos, além de tenderem a reduzir o peso das ideologias. Neste sentido, os candidatos são eleitos por sua proximidade com os eleitores, que são os responsáveis por sua classificação na competição. Os líderes dos partidos tendem a cuidar dos "assuntos domésticos", isso é, são mais voltados para o interior da organização.

Em sistemas de listas fechadas, os candidatos são candidatos porque são líderes na organização. Por isso, tendem a vocalizar mais o programa do partido do que a expressar as opinióes do eleitor. Eventualmente, isso pode levá-los a serem mais "radicais" que seus eleitores ou menos permeáveis ao eleitorado. Assim, deve ser ressaltado que, apesar dos partidos serem estruturas competitivas, o sistema e o ambiente no qual eles disputam podem ter efeitos sobre a produção de uma classe política mais distante ou mais próxima aos eleitores, mais ideológica ou mais pragmática, conforme proposto por Kitschelt (1989).

Outro ponto importante é a sintonia entre a Executiva Municipal do PMDB em Belo Horizonte com os documentos do partido, analisados neste trabalho 
(Programa e Estatuto), que estavam em vigor durante a elaboração desta pesquisa. Como foi destacado, os líderes conhecem os programas do partido e possuem opinióes que, em sua maior parte, estão alinhadas com o programa do PMDB. Este alinhamento parece ser um indício de coesão entre os líderes, pois os documentos partidários são, a priori, feitos para os membros do partido e não para os eleitores, pois tendem a expressar a opiniáo dos membros que compóem o partido e não são elaborados para atender as opinióes dos seus eleitores.

O modelo da "Lei da Disparidade" presume que os eleitores dos partidos são táo pragmáticos quanto os líderes e que estes segmentos partilham semelhantes ideologias. Parece que é este o caso do PMDB, uma vez que a ideologia destes dois grupos se aproxima do centro, conforme a nota de autolocalização dos eleitores e das lideranças. Como proposto por May (1973), tais semelhanças podem advir do fato de que os dirigentes necessitam de votos, o que os leva a se aproximarem dos eleitores. Por outro lado, a estrutura interna do PMDB - mais flexível e menos centralizada pode interferir nas relaçóes entre líderes e eleitores, como indicado por Kitschelt (1989). Melo (2013) examinou a organização do PMDB e observou que, de fato, o PMDB se assemelha mais a um partido de corte loosing coupling, estrutura esta que aumenta as chances de pragmatismo das lideranças.

Os trabalhos posteriores a serem desenvolvidos constituiriam na aplicação de um questionário sucinto aos membros do partido, que não foram contemplados neste artigo. Seguindo exemplo de Mendez e Santamaria (2001), a Convenção Nacional do partido seria o melhor ambiente para testar a "Lei da Disparidade", uma vez que reúnem militantes e lideranças de todo o país, o que possibilita entrevistar membros do partido de diferentes regióes e com diferentes funções no interior da organização. Em consonância com esse estudo, seria necessário uma pesquisa dos documentos do PMDB desde a sua fundação, para desenhar a trajetória ideológica do partido. Com estes estudos, seria possível verificar de modo mais consistente a "Lei da Disparidade".

Em síntese, apesar de este estudo apontar para a semelhança entre o pensamento das lideranças do PMDB e os eleitores identificados com ele, seriam necessários estudos complementares para a sua comprovação. O PMDB - por sua grandeza numérica e sua posição central em eleições brasileiras é um partido que merece ser analisado cuidadosamente, com o uso de teorias para além da rational choice e com metodologias qualitativas e quantitativas. 
- Helcimara de Souza Telles é Professora do Programa de PósGraduação em Ciência Politica da Universidade Federal de Minas Gerais. E-mail: mara-telles@uol.com.br

Paulo Victor Melo é Doutorando em Ciência Política da
$\begin{aligned} & \text { Universidade Federal de Minas Gerais. } \\ & \text { paulovictormelo@gmail.com }\end{aligned}$

\section{Referências}

ALCÁNTARA, Manuel. La ideología de los partidos políticos latino-americanos. In: Seminario de Investigación de Ciencia Política, Universidad de Salamanca, 2004.

AMARAL, Oswaldo M. E. As Transformaçôes na Organização Interna do Partido dos Trabalhadores entre 1995 e 2009. 2010. 306 f. Tese (Doutorado em Ciência Política) - Programa de PósGraduação em Ciência Política, Universidade Estadual de Campinas, Campinas, 2010.

BABBIE, Earl. Métodos de pesquisa de Survey. Belo Horizonte: Editora UFMG, 1999.

BRAGA, Maria do S. S. e PIMENTEL JR, Jair. Os partidos políticos brasileiros realmente não importam? Opinião Pública, Campinas, v. 17, p. 271-303, 2011.

CARREIRÃO, Yan de S. Identificação ideológica, partidos e voto na eleição presidencial de 2006. Opiniáo Pública, Campinas, v. 13, p. 307-339, 2007.

CARREIRÃO, Yan de S.; KINZO, Maria D. Partidos políticos, preferência partidária e decisão eleitoral no Brasil (1989-2002). Dados, Rio de Janeiro, v. 47, n. 1, p. 131- 168, 2004.

CASTRO, Mônica M. M. Determinantes do Comportamento Eleitoral: A Centralidade da Sofisticação Política. 1994. 239f. Tese (Doutorado em Ciência Política) - Programa de Pós Graduação em Ciência Política, Instituto Universitário de Pesquisas do Rio de Janeiro, Rio de Janeiro, 1994.

DOWNS, Anthony. Uma teoria Econômica da Democracia. São Paulo: EDUSP, 1999.

DULCI, Marcelo S. PSDB: forças e limites da resposta liberal aos desafios do Brasil contemporâneo. 2010. Tese (Doutorado em Sociologia e Política) - Programa de Pós Graduação em Filosofia e Ciências Humanas, Universidade Federal de Minas Gerais, Belo Horizonte, 2010.

DUVERGER, Maurice. Os Partidos Políticos. São Paulo: Zahar, 1980.

ESTATUTO DO PMDB. 2007. Disponível em: <http://www.pmdb.org.br>. Acesso em: 07 jun. 2010.

FERREIRA, Denise P.; RIBEIRO, Pedro F. O voto e a máquina: as trajetórias de implementação local de PT e (P) MDB em perspectiva comparada. In: BAQUERO, Marcello; CREMONESE, Dejalma. Eleiçôes Municipais de 2008: uma análise do comportamento eleitoral brasileiro. Ijuí: Editora Ijuí, 2009. p. 127-148.

GRUPO OPINIÃO PÚBLICA e IPESPE. Grupo de Pesquisa "Opinião Pública: Marketing Político e Comportamento Eleitoral” da Universidade Federal de Minas Gerais e Instituto de Pesquisas Sociais, Políticas e Econômicas. Pesquisa BH Barômetro. 2008. 
KECK, Margaret. PT, A Lógica da Diferença: o Partido dos Trabalhadores na construção da democracia brasileira. São Paulo: Ática, 1991.

KENNEDY, Fiachra; LYONS, Pat; FITZGERALD, Peter. Pragmatists, Ideologies and the General Law of Curvilinear Disparity: The Case of the Irish Labor Party. Political Studies, v. 54, p. 786805, 2006.

KINZO, Maria D. Oposição e Autoritarismo: gênese e trajetória do MDB (1966/1979). São Paulo, SP: Vértice, 1988.

. Os Partidos no Eleitorado: percepçóes públicas e laços partidários no Brasil. Revista Brasileira de Ciências Sociais, v. 20, n. 57, p. 65-81, 2005.

KITSCHELT, Herbert. The Internal Politics of Parties: The Law of Curvilinear Disparity Revisited. Political Studies, v. 37, n. 3, p. 400-421, 1989.

MAY, John. Opinion Structure of Political Parties: The Special Law of Curvilinear Disparity. Political Studies, v. 21, n. 2, p. 135-151, 1973.

MELO, Carlos R. e SANTOS, Manuel L. O que informa a ideologia? Uma análise de deputados e partidos no legislativo brasileiro. In: Encontro da $A B C P, 8^{\circ}$, Gramado, 2012.

MELO, Carlos R. O PT e a democracia. 1994. Dissertação de Mestrado. Belo Horizonte, Departamento de Ciência Política, Universidade Federal de Minas Gerais, datilografado. 1994.

. Os Partidos e as Eleições Presidenciais no Brasil. Em Debate, Belo Horizonte, v. 2, n. 6, p. 611, jun. 2010.

MELO, Paulo V. T. P. O PMDB e a sua manutenção no centro do jogo político: de catch all a cartel. 2013. 207f. Dissertação (Mestrado em Ciência Política) - Programa de Pós Graduação em Ciência Política, Universidade Federal de Minas Gerais, Belo Horizonte, 2013.

MÉNDEZ, Mónica; SANTAMARÍA, Julián. La ley de la disparidad ideológica curvilínea de los partidos políticos: el caso del PSOE. Revista Española de Ciencia Política, Madrid, n. 4, p. 35-69, 2001.

MENEGUELLO, Rachel. PT: a formação de um partido, 1979-1982. Rio de Janeiro: Paz e Terra, 1989.

NICOLAU, Jairo. Multipartidarismo e democracia: um estudo sobre o sistema partidário brasileiro (1985-94). Rio de Janeiro: FGV, 1996.

NORRIS, Pippa. May's Law of Curvilinear Disparity Revisited: Leaders, Officers, Member and Voters in British Political Parties. Party Politics, n. 1, v. 1, p. 29-47, 1995.

PAIVA, Denise; TAROUCO, Gabriela da S. Voto e identificação partidária: os partidos brasileiros e a preferência dos eleitores. Opinião Pública, Campinas, v. 17, p. 426-451, 2011.

PROGRAMA DO PMDB. 1996. Disponível em: <http://www.pmdb.org.br>. Acesso em: 07 jun. 2010.

RIBEIRO, Pedro F. Dos sindicatos ao governo: a organização nacional do PT de 1980 a 2005. 2008. 306f. Tese (Doutorado em Ciência Política) - Programa de Pós-Graduação em Ciência Política, Universidade Federal de São Carlos, São Carlos, 2008.

ROMA, Celso. A Social Democracia no Brasil: organização, participação no governo e desempenho eleitoral do PSDB (1988-1998). 1999. Dissertação de Ciência Política (Mestrado em Ciência Política), Universidade de São Paulo, São Paulo, 1999.

- Pragmatismo e ideologia: analisando as decisões das lideranças do PSDB. In: TELLES, Helcimara de S.; LUCAS, João I. Das Ruas às Urnas: partidos e eleiçôes no Brasil contemporâneo. Caxias do Sul: Educs, 2003. p. 49-78. 
Organizaciones de Partido en Brazil: El PT y El PSDB bajo Perspectiva Comparada. América Latina Hoy, Madrid, n. 44, p. 153-184, 2006.

SARTORI, Giovanni. Partidos e Sistemas Partidários. Brasília: UNB, 1976.

TELLES, Helcimara de S.; STORNI, Tiago P. Ideologias, atitudes e decisão de voto em eleitores de direita e de esquerda. Revista Latinoamericana de Opinión Pública, v. 1, p. 87-146, 2011.

TELLES, Helcimara de S. El partido de los trabajadores y la red de militantes. ¿Qué piensan y en qué creen sus dirigentes y sus candidatos? In: ULIONOVA, Olga. Redes Politicas y Militantes. Santiago de Chile, 2009. p. 481-534.

O PT e a ordem - identidade, conflito e interação: um estudo de caso sobre os candidatos a vereador nas eleições de 1992. 1997. Dissertação (Mestrado em Ciência Política), Programa de Pós Graduação em Ciência Política, Belo Horizonte, Universidade Federal de Minas Gerais, 1997.

- Os partidos e a competiçáo política: o desempenho do Partido dos Trabalhadores nas eleiçóes para a Câmara dos Deputados (1982/1998). 2003. Tese (Doutorado em Ciência Política), Programa de Pós Graduação em Ciência Política, Universidade de São Paulo, São Paulo, 2003.

VEIGA, Luciana F. O Partidarismo no Brasil (2002/2010). Opinião Pública, Campinas, v. 17, p. 400425, 2011.

VILlA, Marco A.; ANGELO, Vitor A. (Org.). O Partido dos Trabalhadores e a politica brasileira (1980-2006): uma história revisitada. São Paulo: EDUFSCar, 2009.

Texto recebido em 03 de janeiro de 2014. Aprovado em 10 de março de 2014. 